\title{
13. PRELIMINARY POLLEN ANALYSIS OF QUATERNARY SEDIMENTS FROM DEEP SEA DRILLING PROJECT SITE 565, WESTERN COSTA RICA ${ }^{1}$
}

\author{
Sally P. Horn, Department of Geography, University of California, Berkeley²
}

\begin{abstract}
Preliminary analyses of 32 samples from the upper $24 \mathrm{~m}$ of sediment recovered at Site 565 show changes in pollen frequencies that appear to reflect vegetational and climatic changes in southern Central America during the late Quaternary. Four pollen zones are recognized. In the lowest zone, Zone 4, the tropical pollen types Urticales, Piper, and Alchornea are common. Temperate forest taxa, particularly Pinus, Quercus, and Podocarpus, dominate Zones 3 and 2. Pollen spectra in Zone 1 are variable and show peaks in both temperate and tropical taxa. The record is estimated to cover most of the last glacial cycle.
\end{abstract}

\section{INTRODUCTION}

Pollen analysis of sediment samples from the ocean basins began in the 1950s, and since that time a number of investigators have used the pollen content of marine sediment cores to reconstruct the Quaternary environmental history of adjacent land masses (Groot and Groot, 1966; Rossignol-Strick and Duzer, 1976; Heusser, 1978; Van Campo et al., 1982). To date, however, few palynological studies of marine sediments from the New World tropics have been published.

In 1959, Muller described the palynology of surficial sediments collected in the Orinoco Delta and documented the importance of stream processes in delivering pollen and spores to the continental shelf. Muller's pioneering work was followed by studies of contemporary pollen deposition in the Great Bahama Bank (Traverse and Ginsburg, 1966) and the Gulf of California (Cross et al., 1966). In 1970, Habib et al. described the pollen stratigraphy of two short cores from the Middle America Trench off Tehuantepec; they related changes in pollen concentrations and frequencies to Holocene climatic fluctuations in adjacent Mexico. More recently, Byrne (1982), Heusser (1982), and Sirkin (1982) discussed the pollen stratigraphy of Quaternary sediments from the Gulf of California.

This chapter summarizes the preliminary results of pollen analysis of marine sediment cores from Deep Sea Drilling Project Site 565, on the lower continental slope off western Costa Rica. The analysis was restricted to the upper $24 \mathrm{~m}$ of sediment recovered at the site in the hope of obtaining a record of late Quaternary environmental conditions.

\section{PREVIOUS STUDIES}

Since the 1960s, considerable progress has been made in deciphering the Quaternary vegetational and climatic

\footnotetext{
${ }^{1}$ von Huene, R., Aubouin, J., et al., Init. Repts. DSDP, 84: Washington (U.S. Govt. Printing Office).

2 Address: Department of Geography, 501 Earth Sciences Building, University of California, Berkeley, Berkeley, CA 94720.
}

history of the neotropics. Particularly important here has been the series of palynological studies carried out by van der Hammen and associates in northern South America, and by Tsukada and Deevey and associates in the Mayan lowlands of Guatemala. The results of these studies are summarized in the recent review of tropical palynology by Flenley (1979), and in earlier review papers by van der Hammen (1974), and Tsukada and Deevey (1967). Important recent work missed by these reviews includes an analysis of the pollen stratigraphy of Holocene sediments in the Amazon basin by Absy (1979), and a detailed study of the paleontological, chemical, and mineralogical content of a sediment core from Lake Valencia, Venezuela, by Bradbury et al. (1981).

Southern Central America has received much less attention from Quaternary palynologists. Bartlett and Barghoorn (1973) have examined the fossil pollen content of deep cores from the Gatun basin of Panama. The sediments investigated were deposited in a coastal swamp under the influence of the postglacial rise in sea level, and most of the vegetational changes discernible in the diagrams appear to reflect alterations of edaphic conditions owing to sea level changes. Sediments deposited from 11,300 to 9600 years ago contained evidence of an apparent downslope migration of some montane forest taxa that was interpreted to reflect cooler climatic conditions during this period.

Prior to the present study, only one pollen record was available from Costa Rica. Martin (1964) analyzed the pollen content of a $13-\mathrm{m}$ core from a montane bog in the Cordillera de Talamanca (elevation $2400 \mathrm{~m}$ ) and found two sections in his core in which nonarboreal pollen and spores of Lycopodium and Isoetes were abundant, and pollen of Quercus and other montane forest trees was scarce. He interpreted these zones, the most recent of which was dated at 20,750 years ago, to reflect a regional shift in vegetation from montane rain forest to páramo as a result of climatic cooling during the Wisconsinan. As this chapter indicates, the pollen record from Site 565 provides further evidence of significant vegetational and climatic changes in Costa Rica during the late Quaternary. 


\section{ENVIRONMENTAL SETTING}

Deep Sea Drilling Project Site 565 is located on a submarine interfluve approximately $42 \mathrm{~km}$ west of the coast of the Nicoya Peninsula of Costa Rica $\left(9^{\circ} 43.69^{\prime} \mathrm{N}\right.$; $86^{\circ} 05.44^{\prime} \mathrm{W}$ ), at a water depth of $\sim 3111 \mathrm{~m}$ (Fig. 1). The present oceanic circulation is dominated by the northward flowing Costa Rica coastal current (U.S. Navy Hydrographic Office, 1947). Prevailing winds are southwesterly from May to October, and northerly or northeasterly from November to April (Hastenrath and Lamb, 1977).

The mountainous backbone of Central America divides adjacent western Costa Rica into two broad physiographic provinces: the Pacific lowlands and the Central highlands. The Pacific lowlands include a series of peninsulas and low coastal hills composed of sedimentary and volcanic rocks. The Central highlands are formed by a chain of Quaternary volcanoes and by the plutonic massif of the Cordillera de Talamanca (Castillo-Muñoz, 1983). Elevations range from $1500 \mathrm{~m}$ at the northernmost volcanoes to over $3800 \mathrm{~m}$ in the Cordillera de Talamanca. The major streams draining the highlands are shown in Figure 1.

Annual mean temperatures on the Pacific slope of Costa Rica range from more than $27^{\circ} \mathrm{C}$ in the lowlands to less than $8^{\circ} \mathrm{C}$ on the highest peaks. Precipitation is strongly seasonal. In the lowlands of northwestern Costa Rica the wet season lasts from about May to November, and annual precipitation averages 1500 to $2000 \mathrm{~mm}$. The length of the rainy season and total annual precipitation increases with increasing distance southward. In the Golfo Dulce region of southwestern Costa Rica the wet season lasts from mid-May to December, and annual precipitation totals reach 4000 to $5000 \mathrm{~mm}$. The Central highlands receive 2000 to $6000 \mathrm{~mm}$ rainfall annually (Coen, 1983). Fog and mists are frequent in the highlands and constitute a significant source of additional moisture.

The lowlands of northwestern Costa Rica support seasonally deciduous dry forest and savanna. The deciduous forests are low and relatively open. Common genera

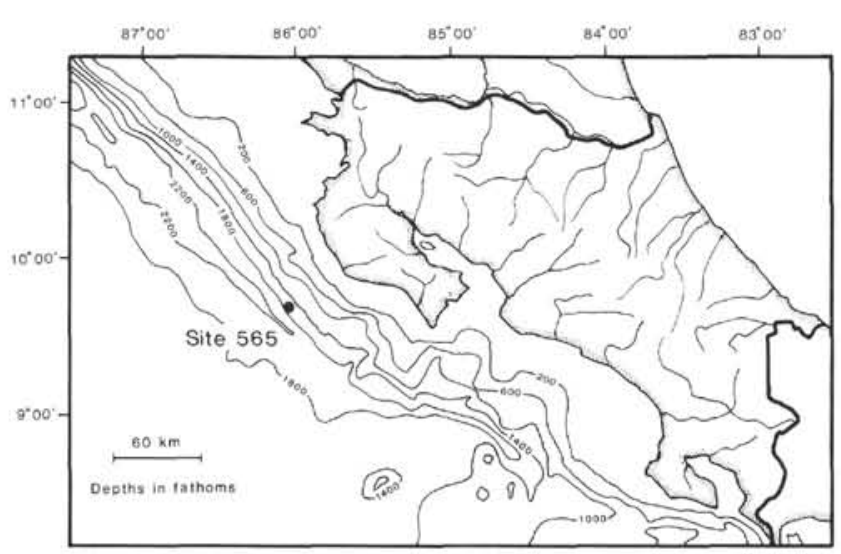

Figure 1. Location and bathymetry of Deep Sea Drilling Project Site 565 and major stream drainages in adjacent Costa Rica. include Bursera, Bombacopsis, Cochlospermum, Enterolobium, Guazuma, Luehea, and Tabebuia (Hartshorn, 1983). The evergreen lowland oak Quercus oleoides reaches its southern limit in Central America in a restricted area of dry forest in the extreme northwest of Costa Ri$\mathrm{ca}$, where it occurs at elevations from 50 to $500 \mathrm{~m}$. Elsewhere in Costa Rica oaks occur principally in highland forests, where they are often a dominant group (Burger, 1977). The savannas of lowland Guanacaste are dominated by introduced African grasses. The present savannas are the result of the clearing and burning of forests, but similar associations may have existed on shallow soils and in swampy areas prior to human settlement (Holdridge, 1953).

With increasing distance southward the tropical dry forests are replaced by taller and denser semideciduous or evergreen tropical moist and wet forests. Common tree and shrub genera in these diverse lowland rain forests include Anacardium, Brosimum, Cecropia, Ficus, Iriartea, Piper, and Virola (Holdridge, 1953; Allen, 1956).

Mangrove forests occur in protected areas along the Pacific coast. The principal species are Rhizophora mangle, Laguncularia racemosa, Avicennia germinans, Conocarpus erectus, and Pelliciera rhizophorae (Allen, 1956).

With increasing altitude the tropical forests of the Pacific lowlands give way to premontane and montane forests in which temperate taxa, particularly Quercus, assume greater importance. At midelevations, common oak associates include Alfaroa, Sapium, Ulmus, and members of the Lauraceae. At higher elevations, Alnus, Drimys, Podocarpus, and Weinmannia become important (Standley, 1937-38). Epiphytic and terrestrial ferns, including the tree ferns Cnemidaria and Cyathea, are particularly abundant in these cool montane forests. Conspicuously absent from these forests is the genus Pinus. Pines form extensive stands in the drier interior highlands of Mexico and northern Central America, but reach their southern limit in Nicaragua (Parsons, 1955).

\section{MODERN POLLEN RAIN}

Modern pollen rain data are available from savanna, mangrove, tropical moist forest, tropical wet forest, and lower montane rain forest formations in Costa Rica and Panama. The pollen assemblages are distinct and generally show good correspondence with vegetation patterns.

Table 1 shows the pollen frequencies in surface samples collected in areas of open savanna and mangrove vegetation in Santa Rosa National Park in northwestern Costa Rica. The savanna sample was collected near the park campground at an elevation of $280 \mathrm{~m}$. As the table indicates, the sample is dominated by herbaceous pollen types, particularly Gramineae and Compositae. Tree and shrub pollen are rare and are represented by occasional grains of Quercus, Pinus, Urticales ${ }^{3}$, Malpighiaceae, and Bauhinia.

\footnotetext{
${ }^{3}$ As used here, following Bartlett and Barghoorn (1973), the Urticales group includes pollen in the Moraceae, Urticaceae, and Ulmaceae families (excluding Ulmus). When wellpreserved, some pollen types (e.g., Cecropia, Celtis, Dorstenia, Ficus, and Trema) can be identified to genus.
} 
Table 1. Pollen percentages in surface sediments from sites in northwestern Costa Rica. Part 1. Open savanna. Part 2. Mangrove wetland.

\begin{tabular}{|c|c|}
\hline Taxon & $\begin{array}{l}\text { Percent } \\
\text { total } \\
\text { pollen }\end{array}$ \\
\hline \multicolumn{2}{|c|}{$\begin{array}{l}\text { Part 1. Open savanna, elevation } 280 \mathrm{~m} \text {, San- } \\
\text { ta Rosa National Park }(\mathrm{N}=253)\end{array}$} \\
\hline Gramineae & 52.6 \\
\hline Compositae high-spine & 18.9 \\
\hline Quercus & 1.6 \\
\hline Chenopodiaceae/Amaranthaceae & .8 \\
\hline Malvaceae & .8 \\
\hline Pinus & .4 \\
\hline Urticales & .4 \\
\hline Malpighiaceae & .4 \\
\hline Bauhinia & .4 \\
\hline Unknown & 12.0 \\
\hline Indeterminate & 11.6 \\
\hline \multicolumn{2}{|c|}{$\begin{array}{l}\text { Part 2. Mangrove wetland, Playa Naranjo, } \\
\text { Santa Rosa National Park }(N=299)\end{array}$} \\
\hline Rhizophora & 60.5 \\
\hline Laguncularia & 6.7 \\
\hline Urticales & 3.3 \\
\hline Anacardiaceae & 2.0 \\
\hline Gramineae & 1.0 \\
\hline Cordia & .3 \\
\hline Unknown & 10.7 \\
\hline Indeterminate & 15.4 \\
\hline
\end{tabular}

The mangrove sample was collected near sea level in the mangrove wetland at Playa Naranjo. The sample is dominated by the pollen of the red mangrove Rhizophora and the white mangrove Laguncularia. Occasional grains of Urticales, Anacardiaceae, and Cordia pollen represent influx from inland tropical dry forest formations.

Bartlett and Barghoorn (1973) have analyzed the pollen content of recent lake sediments collected adjacent to the tropical moist forests of Barro Colorado Island, Panama. Urticales pollen was consistently abundant in each of four samples analyzed, with percentages ranging from about 14 to $26 \%$. Other common pollen types included Apeiba, Acalypha, Alchornea, Cordia, Zanthoxylum, and Melastomataceae.

Surficial marine sediments collected adjacent to the tropical wet forests of the Osa Peninsula in Golfo Dulce, Costa Rica are also dominated by Urticales pollen. This type accounts for $35 \%$ of the total pollen in the uppermost $2 \mathrm{~cm}$ of sediment in two short cores recovered from the Gulf in 1969 and 1970. Other lowland pollen types frequent in these samples include Piper, Alchor$n e a$, and Combretaceae-Melastomataceae. The red mangrove Rhizophora supplies 14 to $21 \%$ of the total pollen. Quercus, Podocarpus, Alfaroa, Alnus, and Ulmus together account for 6 to $16 \%$ of the pollen sum and represent long-distance transport from montane forests (Horn, in press).

The uppermost sample from Martin's (1964) pollen diagram from a montane bog in the Cordillera de Talamanca provides an indication of modern pollen rain in an area of lower montane rain forest. The sample is dominated by Quercus pollen, with lesser amounts of
Podocarpus, Alnus, and Drimys. The pollen of herbs and Ericaceous shrubs growing on the bog are also common.

No data are available from tropical dry forests in southern Central America, but Fine (1978) has analyzed the pollen content of nine surface samples from roughly analagous tropical deciduous forests in southern Mexico. Herbaceous pollen types, particularly Chenopodiaceae-Amaranthaceae, Gramineae, Cyperaceae, and Compositae high-spine, dominated most of the assemblages. Two samples collected near the upper elevational limit of the formation contained more than $30 \%$ Melastomataceae pollen and about 5\% Piper pollen. Neither pollen type was found in other lowland deciduous forest samples, but Piper was occasional in samples from wetter subdeciduous forests at higher elevations.

\section{METHODS}

Drilling operations at Site 565 penetrated a homogeneous sequence of Quaternary to Miocene fine-grained slope sediments. Thirty-four consecutive cores were recovered to a sub-bottom depth of $328 \mathrm{~m}$ (see Site 565 report, this volume). The sediments comprise a single lithologic unit consisting of dark olive gray to dark greenish gray (5Y3 5/2 to 5 GY 4/1) mud grading to mudstone at the base. The sand-silt-clay percentages average 6,13 , and $80 \%$, respectively. Sedimentary structures occur rarely and include beds of lighter-colored silts, small clasts of the same lithology as the mud matrix, and patches of yellowish (10YR 2/1) mottling.

Samples for pollen analysis were taken from the uppermost three cores recovered at the site, at 10 - to 20 -cm intervals in the top meter and at approximately $50-\mathrm{cm}$ intervals thereafter to a depth of $24 \mathrm{~m}$. Thirty-two samples have been analyzed to date and are discussed in this report.

The samples were processed using standard techniques $(10 \% \mathrm{HCl}$, $52 \% \mathrm{HF}, 35 \% \mathrm{HNO}_{3}$, and acetolysis). Details of the method have been described elsewhere (Horn, 1983). Prior to extraction, a known quantity of Lycopodium spores was added to each sample as a control (Stockmarr, 1971). Residues were mounted in silicon oil and counted to a total of at least 200 pollen grains. Spores were then calculated outside the pollen sum and identifications were based on a regional reference collection.

\section{CHRONOLOGY}

Radiocarbon dates were obtained for two samples from the top $35 \mathrm{~cm}$ of Core 1 to determine the upper age boundary of the Site 565 pollen record. The analyses were performed by Beta Analytic Laboratory using the benzene method. As Table 2 indicates, the dates for both samples are younger than $6000 \mathrm{yr}$. The dates have

Table 2. Radiocarbon dates, Site 565.

\begin{tabular}{cccc}
\hline $\begin{array}{c}\text { Laboratory } \\
\text { No. }\end{array}$ & $\begin{array}{c}\text { Sample } \\
\text { (interval in cm) }\end{array}$ & $\begin{array}{c}\text { Sub-bottom } \\
\text { depth } \\
\text { (cm) }\end{array}$ & $\begin{array}{c}{ }^{14} \mathrm{C} \text { age in } \\
\text { radiocarbon years }\end{array}$ \\
\hline $\begin{array}{c}\text { Beta-6143 } \\
\text { Beta-6144 }\end{array}$ & $565-1-1,0-14$ & $0-14$ & $2420 \pm 140$ \\
\hline
\end{tabular}

a By international convention, the dates shown here have been calculated on the basis of a radiocarbon half-life of 5568 years. Present evidence favors a half-life of 5730 years, which would add approximately 73 years to the younger date and 164 years to the older date (M. Tamers, personal communication, 1983). The dates have not been corrected for the natural variation in atmospheric ${ }^{14} \mathrm{C}$ (the DeVries effect). This correction would not substantially change the younger date, but would add $\sim 600$ years to the older date (M. Tamers, personal communication, 1983). 
not been corrected for isotopic fractionation in nature or the marine reservoir effect. These corrections are difficult to make because the composition and source of the organic matter dated is not known. Because of this uncertainty, and because of probable drilling disturbance at the top of the core, the dates should be considered as approximations. They indicate, however, that at least part of the Holocene is represented in the Site 565 pollen record.

No isotopic dates are available for lower levels in the pollen diagram, but a tentative estimate of the time interval represented by the record is provided by the biostratigraphy of the Site 565 cores. On the basis of the inferred position of the lower boundary of the Gephyrocapsa oceanica Nannofossil Zone at about $80 \mathrm{~m}$ at Hole 565 , Leg 84 biostratigraphers have estimated a late Pleistocene sedimentation rate of $16.5 \mathrm{~cm} / 1000 \mathrm{yr}$. (see Site 565 report, this volume). Assuming this rate to have prevailed during the deposition of the 24-m section analyzed here provides an estimated basal date for the pollen record of $\sim 145,000 \mathrm{yr}$. old.

In view of the topographic position of the core site, it should be pointed out that there may be chronological breaks or discontinuities in the record. The lack of distinct sedimentary structures in the Site 565 cores may be the result in part of homogenization of the sediments by mass movement. The possible magnitude of such disturbance is difficult to assess without additional isotopic or biostratigraphic data. Hopefully, future studies will provide this information and establish a firmer chronological framework for the Site 565 pollen record.

\section{RESULTS}

Figure 2, the percentage pollen diagram, summarizes the pollen data for the major taxa encountered at Site 565. Rhizophora has been excluded from the pollen sum in this case to emphasize changes in nonlittoral vegetation. Raw counts for all pollen and spore types appear in Appendixes A and B. Plates 1 through 5 illustrate some of the palynomorphs.

Pollen is moderately abundant in the Site 565 sediments, with concentrations ranging from approximately 6000 to 24,000 pollen grains and spores per gram dry weight of sediment (Appendix A). Palynomorph preservation ranges from good to poor within each sample, with spores especially showing signs of bacterial or fungal attack.

Approximately ninety pollen types have been recognized, most occurring in low frequencies. The most common pollen types are Pinus, Podocarpus, Quercus, Alfaroa-Oreomunnea, Alnus, Hedyosmum, Piper, Alchornea, Rhizophora, Urticales, Combretaceae-Melastomataceae, Gramineae, Cyperaceae, Compositae, and Amaranthaceae. Pollen designated as "ERA-type" is also frequent in the samples and probably represents the Euphorbiaceae, Rutaceae, and Anacardiaceae families. When well preserved, some pollen types in this group could be identified to genus.

Fern spores are abundant. Approximately 30 morphological types have been recognized. Most types have not been identified and many probably represent broad groups. Identified types include Cnemidaria $(=$ Hemi-

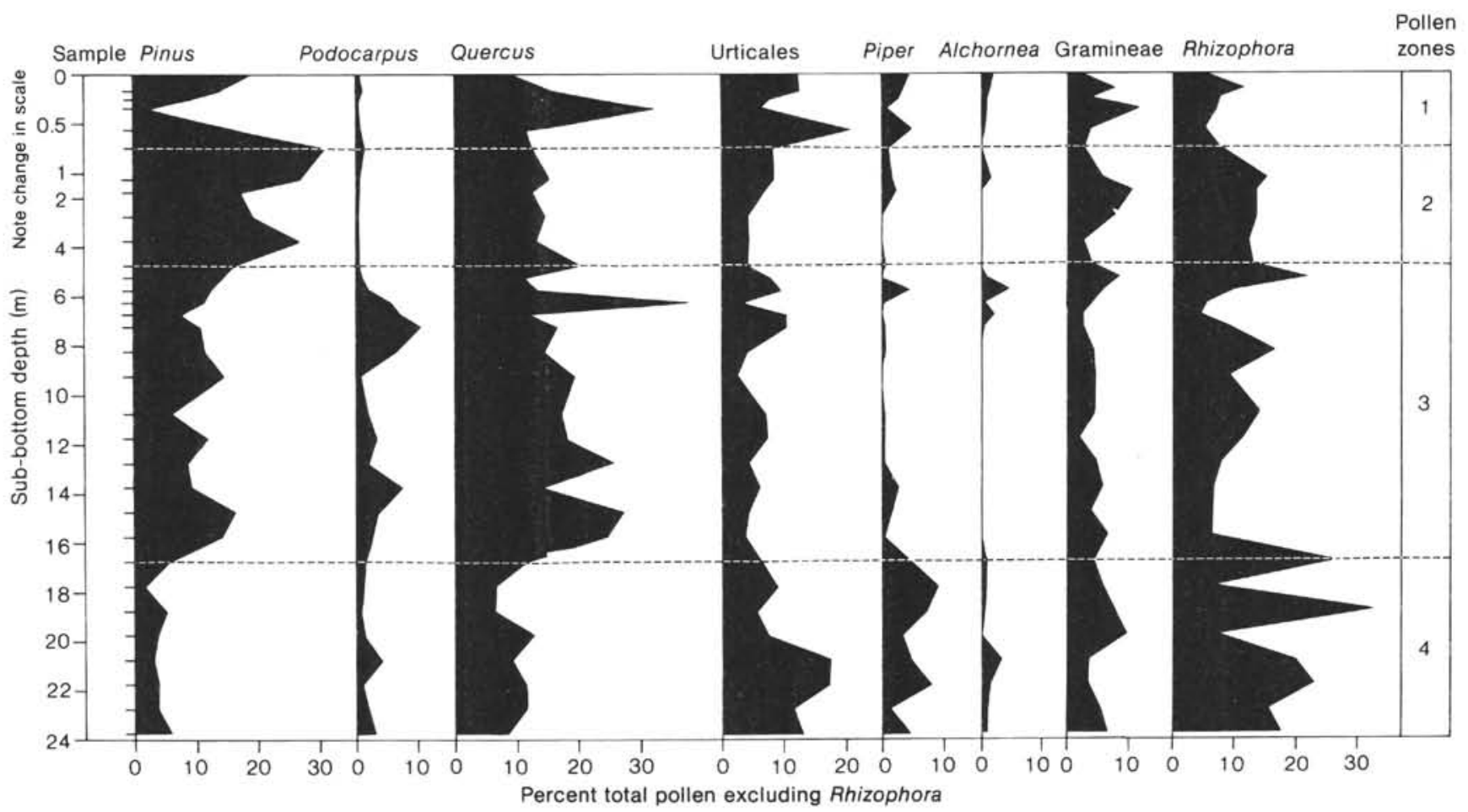

Figure 2. Percentage pollen diagram, Site 565, 0 to 24 meters, showing Pollen Zones 1 to 4 . 
telia), Cyathea, Pteris, Hymenophyllaceae, Ophioglossaceae, and Polypodiaceae.

Other palynomorphs observed but not counted include fungal spores, dinoflagellate cysts, microforaminifers, and the form genus Concentricystis. Charred plant fragments are common in some samples. Reworked pollen and spores appear to be rare.

For purposes of discussion, the Site 565 pollen diagram is provisionally divided into four zones on the basis of the distribution of the most common pollen types. The basal pollen zone, Zone 4 , is characterized by consistently low percentages $(\leq 6 \%)$ of pine pollen. In only two samples outside this zone (Samples 565-1-1, 36-38 $\mathrm{cm}$ and $565-2-1,25-27 \mathrm{~cm}$ ) are pine frequencies as low. Quercus and Podocarpus also show relatively low percentages in Zone 4. Piper reaches its highest recorded frequencies within the zone, as does Rhizophora, which shows marked fluctuations. In the lower half of the zone, Urticales pollen is common, accounting for 11 to $17 \%$ of the pollen sum, values that are not reached again until Zone 1 (Samples 565-1-1, 1-3 cm; 565-1-1, 17-19 cm; and 565-1-1, 56-58 cm). Alchornea pollen is present in low frequencies in all but one sample from the zone.

The beginning of Zone 3 is marked by a sharp increase in pine and oak percentages. Pine values approximately triple, increasing from an average of slightly over $4 \%$ in Zone 4 to $12 \%$ in Zone 3 . The percentage of oak pollen approximately doubles, with the type attaining its highest recorded frequency $(38 \%)$ in one sample from near the top of the zone (Sample 565-1-5, 25-27 cm). Podocarpus frequencies also increase, particularly toward the top of Zone 3. Piper and Alchornea pollen are generally scarce, although both types show small peaks near the top of the zone. Rhizophora declines from 26 to $6 \%$ of the pollen sum at the beginning of the zone and then fluctuates around an average of about $11 \%$.

In Zone 2, pine pollen rises to maximum values for all of the samples analyzed, reaching $31 \%$ at the top of the zone. Podocarpus percentages decline at the beginning of Zone 2, remaining low throughout the zone and in Zone 1. Toward the top of Zone 2, Urticales, Piper, and Alchornea percentages begin to increase.

The boundary between Zones 2 and 1 has been provisionally placed at a depth of $.76 \mathrm{~m}$, above which point pine percentages decline sharply and Urticales and Piper percentages increase. Quercus show a sharp peak in the central part of the zone, coincident with the lowest pine level. Toward the top of the zone pine percentages rise again, and oak percentages decline.

\section{DISCUSSION}

The pollen concentrations in the Site 565 sediments are lower than would be expected in lakes or peat bogs (at least in the temperate zone), but are comparable to pollen and spore concentrations reported for other marine cores (Habib et al., 1970; Byrne, 1982; Heusser, 1982). No consistent relationship between palynomorph concentrations and the frequency of particular pollen types was observed. Muller (1959) found that Rhizophora percentages were inversely proportional to the total pollen content in surface sediments from the Orinoco Del- ta, but this relationship does not seem to hold in core samples from Site 565 .

The range in the state of preservation of the Site 565 palynomorphs is similar to that noted by Bartlett and Barghoorn (1973) in their study of the fossil pollen content of deep cores from the Gatun basin of Panama. Corrosion patterns on fern spores resemble those described and pictured by the authors and by Elsik (1966).

As Groot and Groot (1966) have emphasized, the pollen grains and spores found in marine sediments may have complex depositional histories. Unlike lakes and peat bogs, which trap primarily the windblown pollen of the local vegetation, the ocean basins collect pollen and spores transported over long distances by both wind and water. Marine pollen spectra tend, therefore, to integrate the pollen rain over large areas and to reflect regional rather than local vegetation. As a consequence of this wider focus, marine pollen diagrams often provide less sensitive records of environmental change than do terrestrial pollen diagrams (Byrne, 1982).

This is to some extent the case with the Site 565 record. The frequencies of several pollen types show only minor changes from top to bottom of the section. However, certain taxa show more marked variations that appear to reflect vegetational changes in southern Central America during the late Quaternary.

Major changes in the distribution of plant communities are suggested by the changes in pollen frequencies from Zone 4 to Zone 3. The low pine, oak, and podocarp percentages below the Zone $4 / 3$ boundary suggest that these anemophilous temperate taxa occupied a relatively restricted range in southern Central America during the deposition of the basal pollen zone. Tropical taxa in the Urticales group and in the genera Piper and $\mathrm{Al}$ chornea were, in contrast, relatively widespread. These taxa presently occupy varied habitats in Costa Rica, but are particularly well-represented in moist and wet lowland forests, and appear to provide indicator pollen types for this type of vegetation (Horn, 1983). Their importance in Zone 4 suggests that a relatively warm and moist climate prevailed during the deposition of the zone, an interpretation that would be consistent with the low percentages of temperate forest taxa. Extrapolation from sedimentation rates (see the section on Chronology in this chapter) provides an estimated age of from 100,000 to 145,000 yr. for Zone 4 , which suggests that this interval may correspond in part to the last interglacial.

The steep increase in pine and oak percentages at the beginning of Zone 3 and the concomitant decline in tropical pollen types appear to indicate the onset of cooler climatic conditions. If the tentative chronology suggested here is correct, this change may correspond to the beginning of the Wisconsinan glacial. In Costa Rica, Quercus and Podocarpus expanded their ranges, with the latter genus becoming particularly widespread toward the end of the interval, and elsewhere in Central America pines became more important.

Pollen Zone 3 extends through about $12 \mathrm{~m}$ of sediment, and probably represents a considerable amount of time, perhaps most of the early and middle Wisconsinan. The continued dominance of temperate forest taxa 
suggests that the climate during this interval was generally cool, but fluctuations probably occurred. Of possible significance here are the peaks in Piper and Alchornea pollen near the top of the zone, which might indicate a brief interval of climatic warming.

The steep increase in pine pollen at the beginning of Zone 2 suggests a significant expansion of pine forests in Central America, possibly resulting from a shift to cooler or drier conditions during what may correspond to the late Wisconsinan. If this correlation holds, it is interesting to note that there is no evidence for an expansion of open savanna vegetation in northwestern Costa Rica during this period, as has been suggested for the Amazon basin (Haffer, 1969; Prance, 1982). Gramineae pollen shows a peak in the central part of the zone that could reflect the spread of open vegetation on a local scale, but this pollen type does not show the consistently high values that would be expected if a wholesale replacement of forest vegetation by savanna had taken place at this time.

The sharp decline in pine percentages and the rise in Urticales and Piper pollen that mark the beginning of Zone 1 suggest an expansion of tropical forest vegetation at the expense of pines. The radiocarbon dates establish that at least the upper part of Zone 1 dates to the Holocene, and the beginning of the zone may correspond to the Pleistocene/Holocene boundary. Pollen studies at Lake Valencia, Venezuela (Salgado-Labouriau, 1980; Bradbury et al., 1981) and elsewhere in the New World equatorial tropics (Flenley, 1979) have shown that the end of the last glaciation was marked by a change to a warmer and wetter climate, an interpretation that would not be inconsistent with the shifts in pollen frequencies at the beginning of Zone 1 .

Changes within the uppermost pollen zone are, however, complicated, and are difficult to reconcile with other records of Holocene climatic changes in the neotropics. At present it is uncertain how much of this variation reflects true environmental fluctuations and how much may be the result of drilling disturbance at the top of the core. Although all four pollen zones may have been affected by sediment mixing during the coring operation, the likelihood of significant disturbance is probably greater near the top of the section. As Gartner (1977) has noted, the soft uppermost sediments of the ocean basins are extremely difficult to core and to recover without disturbance.

Particularly puzzling aspects of Zone 1 are the sharp peak in oak pollen in the middle of the zone and the resurgence of pine at the top of the section. Further sampling would possibly help to elucidate these shifts, but unfortunately, most of the sample from this interval was consumed in the radiocarbon analyses. To reconstruct Holocene environmental fluctuations in western Costa Rica it will be necessary to study sections from piston or box cores, which are recovered with less disturbance and can be meaningfully sampled at close intervals.

\section{CONCLUSION}

The Site 565 pollen record indicates that the vegetation of southern Central America changed during the late Quaternary, presumably in response to climatic oscillations. The pollen spectra in the basal zone suggest a relatively warm and wet climatic episode that may correspond in part to the last interglacial. A moist tropical forest covered the lowlands adjacent to the core site during this interval, and pine and other temperate forest taxa occupied restricted ranges. The pollen assemblages in the upper section of the record indicate a shift toward cooler and possibly drier climatic conditions, which led to an expansion of montane forest taxa at the expense of more tropical vegetation. This interval appears to represent the early and late Wisconsinan. The uppermost pollen zone dates at least in part to the Holocene and contains pollen assemblages that are variable but that are generally suggestive of a shift toward warmer and wetter conditions and an increased importance of tropical taxa in areas adjacent to the core site.

The pollen data from Site 565 confirm the results of Martin's (1964) investigation of the pollen stratigraphy of a high-elevation bog in Costa Rica, which indicated a major altitudinal depression of montane vegetation zones during the Wisconsinan glacial. The evidence for a formerly more widespread distribution of Podocarpus and Quercus in Costa Rica is consistent with the recent discoveries of possibly relict populations of Podocarpus montanus below $500 \mathrm{~m}$ in the northern Atlantic lowlands of Costa Rica (L. D. Gómez, personal communication, 1984), and of an as yet unidentified species of Quercus at elevations below $750 \mathrm{~m}$ on the Osa Peninsula along the southwestern coast (Herwitz, 1981). The results of the present study are also in broad agreement with the more detailed palynological analyses carried out by van der Hammen and associates in the Sabana de Bogotá in Colombia (van der Hammen, 1974, 1979).

The Site 565 pollen record provides no evidence, however, of a widespread replacement of tropical forests by savannas in western Costa Rica during the late Pleistocene, as has been suggested for the Amazon basin. Past variations in temperature and moisture availability in the Pacific lowlands of Costa Rica more likely resulted in changes in the composition of lowland forests, with wet-habitat trees and shrubs dominating during periods of greater effective moisture, and more drought-tolerant species expanding their ranges during drier phases. The nature and chronology of these changes is presently unclear, as the heavy input of pollen from montane sources masks indications of a lowland vegetation change in the Site 565 record. However, it may eventually be possible to obtain a more complete record of environmental changes in the Pacific lowlands of Costa Rica by excluding montane forest taxa from the pollen sum and by increasing the count of rare but potentially significant lowland pollen types.

\section{ACKNOWLEDGMENTS}

I would like to thank R. Byrne for his advice on the analysis of the Site 565 sediments and B. Leyden, L. Heusser, and D. Habib for their critical reviews of the manuscript. I also thank A. Altman and D. Allard for help with core sampling, and A. Morgan for drafting Figure 2.

This study was supported by a National Science Foundation Graduate Fellowship and by several research and travel grants provided by 
the Dean of the Graduate Division and the Committee on Intercampus Research of the University of California, Berkeley.

\section{REFERENCES}

Absy, M. L., 1979. A Palynological Study of Holocene Sediments in the Amazon Basin: Manaus (Instituto Nacional de Pesquisas da Amazônia).

Allen, P. H., 1956. The Rain Forests of Golfo Dulce: Gainesville (University of Florida Press).

Bartlett, A. S., and Barghoorn, E. S., 1973. Phytogeographic history of the Isthmus of Panama during the past 12,000 years (a history of vegetation, climate, and sea-level change). In Graham, A. (Ed.), Vegetation and Vegetational History of Northern Latin America: Amsterdam (Elsevier), pp. 203-229.

Bradbury, J. P., Leyden, B., Salgado-Labouriau, M., Lewis, W. M., Jr., Schubert, C., Binford, M. W., Frey, D. G., Whitehead, D. R., and Weibezahn, F. H., 1981. Late Quaternary environmental history of Lake Valencia, Venezuela. Science, 214:1299-1305.

Burger, W. B. (Ed.), 1977. Flora Costaricensis. Fieldiana, Bot., 40: $1-291$.

Byrne, R., 1982. Preliminary pollen analysis of Deep Sea Drilling Project Leg 64, Hole 480, Cores 1-11. In Curray, J. R., and Moore, D. G., et al., Init. Repts. DSDP, 64:Washington (U.S. Govt. Printing Office), 1225-1237.

Castillo-Muñoz, R., 1983. Geology. In Janzen, D. H. (Ed.), Costa Rican Natural History: Chicago (University of Chicago Press), pp. 47-62.

Coen, E., 1983. Climate. In Janzen, D. H. (Ed.), Costa Rican Natural History: Chicago (University of Chicago Press), pp. 35-46.

Cross, A. T., Thompson, G. G., and Zaitzeff, J. B., 1966. Source and distribution of palynomorphs in bottom sediments, southern part of the Gulf of California. Mar. Geol., 4:467-524.

Elsik, W. C., 1966. Biological degradation of fossil pollen grains and spores. Micropaleontology, 12(4):515-518.

Fine, B. L., 1978. Vegetation and modern pollen spectra in Sinaloa and Nayarit, Mexico [M.S. thesis]. University of Arizona, Tucson.

Flenley, J. R., 1979. The Equatorial Rain Forest: a Geological History: London (Butterworths).

Gartner, S., Jr., 1977. Calcareous nannofossil biostratigraphy and revised zonation of the Pleistocene. Mar. Micropaleontol., 2:1-25.

Groot, J. J., and Groot, C. R., 1966. Pollen spectra from deep-sea sediments as indicators of climatic changes in southern South America. Mar. Geol., 4:525-537.

Habib, D., Thurber, D., Ross, D., and Donahue, J., 1970. Holocene palynology of the Middle American Trench near Tehuantepec, Mexico. Mem. Geol. Soc. Am., 126:233-261.

Haffer, J., 1969. Speciation in Amazon forest birds. Science, 165; 131-137.

Hammen, T. van der, 1974. The Pleistocene changes of vegetation and climate in tropical South America. J. Biogeogr., 1:3-26. 1979. History of the flora, vegetation, and climate in the Colombian Cordillera during the last five million years. In Larsen, K., and Holm-Nielsen, B. (Eds.), Tropical Botany: New York (Academic Press).

Hartshorn, G. S., 1983. Plants: introduction. In Janzen, D. H. (Ed.), Costa Rican Natural History: Chicago (University of Chicago Press), pp. 118-157.

Hastenrath, S., and Lamb, P. J., 1977. Climatic Atlas of the Tropical Atlantic and Eastern Pacific Oceans: Madison (University of Wisconsin Press).
Herwitz, S. R., 1981. Landforms under a tropical wet forest cover on the Osa Peninsula, Costa Rica. Z. Geomorph. F.N., 25(3):259-270.

Heusser, L., 1978. Pollen in Santa Barbara Basin, California: a 12,000 year record. Geol. Soc. Am. Bull., 89:673-678.

1982. Pollen analysis of laminated and homogeneous sediment from the Guaymas Basin, Gulf of California. In Curray, J. R., and Moore, D. G., et al., Init. Repts. DSDP, 64: Washington (U.S. Govt. Printing Office), 1217-1223.

Holdridge, L. R., 1953. La vegetación de Costa Rica. In Trejos, E. W., and Archer, A. (Eds.), Atlas Estadístico de Costa Rica: San José (Ministerio de Economía y Hacienda y Dirección General de Estadística y Censos), pp. 32-33.

Horn, S. P., 1983. Late Quaternary vegetation change in western Costa Rica: pollen evidence from Deep Sea Drilling Project Site 565 [M.A. thesis]. University of California, Berkeley.

, in press. Estudio palinológico preliminar de dos núcleos cortos del Golfo Dulce, Costa Rica. Mem. V Coloquio sobre Paleobotánica y Palinologia: Mexico City (Escuela Nacional de Ciencias Biológicas).

Martin, P. S., 1964. Paleoclimatology and a tropical pollen profile. In Report of the VIth International Congress on Quaternary, Warsaw, 1961, (Vol. 2), pp. 319-323.

Muller, J., 1959. Palynology of recent Orinoco delta and shelf sediments. Micropaleontology, 5(1):1-32.

Parsons, J. J., 1955. The Miskito pine savanna of Nicaragua and Honduras. Ann. Assoc. Am. Geogr., 45(1):36-63.

Prance, G. T., 1982. Biological Diversification in the Tropics: New York (Columbia University Press).

Rossignol-Strick, M., and Duzer, D., 1976. West African vegetation and climate since 22,500 B.P. from deep-sea cores palynology. Pollen Spores, 21(1-2):105-134.

Salgado-Labouriau, M. L., 1980. A pollen diagram from the Pleistocene-Holocene boundary of Lake Valencia, Venezuela. Rev. Palaeobot. Palynol., 30:297-312.

Sirkin, L., 1982. Preliminary palynology of Pleistocene sediments from Deep Sea Drilling Project sites 474 and 479. In Curray, J. R., and Moore, D. G., et al., Init. Repts. DSDP, 64: Washington (U.S. Govt. Printing Office), 1211-1215.

Standley, P. C., 1937-38. Flora of Costa Rica. Field. Mus. Nat. Hist. Publ. Bot. Ser., 18(1-4):1-1571.

Stockmarr, J., 1971. Tablets with spores used in absolute pollen analysis. Pollen Spores, 13:615-621.

Traverse, A., and Ginsburg, R. N., 1966. Palynology of the surface sediments of the Great Bahama bank, as related to water movement and sedimentation. Mar. Geol., 4:417-459.

Tsukada, M., and Deevey, E. S., Jr., 1967. Pollen analysis from four lakes in the southern Maya area of Guatemala and El Salvador. In Cushing, E. J., and Wright, H. E. (Eds.), Quaternary Paleoecology: New Haven (Yale University Press), pp. 303-331.

U.S. Navy Hydrographic Office, 1947. Atlas of Surface Currents, Northeastern Pacific Ocean: Washington (U.S. Govt. Printing Office).

van Campo, E., Duplessy, J. C., and Rossignol-Strick, M., 1982. Climatic conditions deduced from a 150-kyr oxygen isotope-pollen record from the Arabian sea. Nature, 296:56-59.

Date of Initial Receipt: 27 July 1983

Date of Acceptance: 1 February 1984 
APPENDIX A

Pollen and Spore Counts, Site 565

\begin{tabular}{|c|c|c|c|c|c|c|c|c|c|c|c|c|c|c|c|}
\hline \multirow[b]{2}{*}{ Taxon } & \multicolumn{15}{|c|}{$\begin{array}{c}\text { Sample (interval in cm) } \\
\text { (sub-bottom depth in meters) }\end{array}$} \\
\hline & $\begin{array}{l}1-1, \\
1-3 \\
(.01)\end{array}$ & $\begin{array}{c}1-1 . \\
17-19 \\
(.17)\end{array}$ & $\begin{array}{c}1-1 \\
26-28 \\
(.26)\end{array}$ & $\begin{array}{c}1-1, \\
36-38 \\
(.36)\end{array}$ & $\begin{array}{l}1-1 . \\
56-58 \\
(.56)\end{array}$ & $\begin{array}{c}1-1, \\
76-78 \\
(.76)\end{array}$ & $\begin{array}{c}1-1 \\
125-127 \\
(1.25)\end{array}$ & $\begin{array}{c}1-2, \\
25-27 \\
(1.75)\end{array}$ & $\begin{array}{c}1-2 \\
125-127 \\
(2.75)\end{array}$ & $\begin{array}{l}1-3 \\
75-77 \\
(3.75)\end{array}$ & $\begin{array}{l}1.4 \\
25-27 \\
(4.75)\end{array}$ & $\begin{array}{c}1-4 \\
75-77 \\
(5.25)\end{array}$ & $\begin{array}{c}1-4 \\
125-127 \\
(5.75)\end{array}$ & $\begin{array}{c}1-5, \\
25-27 \\
(6.25)\end{array}$ & $\begin{array}{c}1-5 \\
75-77 \\
(6.75)\end{array}$ \\
\hline $\mathrm{TCT}^{\mathrm{a}}$ & 1 & 0 & 0 & 0 & 0 & 0 & 0 & 0 & 0 & 0 & 0 & 0 & 0 & 0 & 1 \\
\hline Pinus & 40 & 28 & 19 & 4 & 39 & 86 & 48 & 33 & 37 & 60 & 33 & 29 & 25 & 36 & 15 \\
\hline Podocarpus & 1 & 2 & 1 & 1 & 2 & 4 & 1 & 1 & 1 & 1 & 1 & 2 & 4 & 18 & 14 \\
\hline Amaranthaceae & 1 & 2 & 4 & 1 & 2 & 0 & 3 & 3 & 3 & 7 & 1 & 1 & 2 & 1 & 0 \\
\hline Alternanthera-type & 0 & 1 & 0 & 2 & 0 & 0 & 1 & 1 & 0 & 0 & 0 & 0 & 0 & 0 & 1 \\
\hline Anacardiaceae & 0 & 0 & 1 & 1 & 0 & 0 & 3 & 0 & 0 & 2 & 0 & 2 & 0 & 0 & 0 \\
\hline Anacardium-type & 0 & 0 & 0 & 0 & 0 & 0 & 0 & 0 & 0 & 0 & 0 & 0 & 0 & 2 & 0 \\
\hline Spondias-type & 0 & 0 & 0 & 0 & 0 & 1 & 0 & 1 & 1 & 0 & 0 & 0 & 0 & 0 & 0 \\
\hline llex & 0 & 0 & 0 & 0 & 0 & 0 & 0 & 0 & 0 & 0 & 0 & 0 & 0 & 0 & 2 \\
\hline Alnus & 1 & 5 & 4 & 3 & 5 & 4 & 1 & 7 & 10 & 6 & 8 & 6 & 1 & 5 & 3 \\
\hline Bombacaceae & 0 & 0 & 0 & 0 & 0 & 0 & 0 & 1 & 0 & 0 & 1 & 0 & 0 & 0 & 0 \\
\hline Cordia & 0 & 0 & 0 & 0 & 0 & 1 & 0 & 2 & 2 & 1 & 0 & 0 & 0 & 1 & 0 \\
\hline Bursera & 1 & 1 & 0 & 0 & 0 & 1 & 1 & 1 & 2 & 1 & 0 & 2 & 0 & 0 & 2 \\
\hline Caryophyllaceac & 1 & 0 & 0 & 1 & 5 & 0 & 1 & 0 & 0 & 2 & 2 & 1 & 0 & 0 & 0 \\
\hline Hedyosmum & 1 & 4 & 0 & 0 & 1 & 3 & 2 & 0 & 6 & 2 & 0 & 1 & 4 & 0 & 2 \\
\hline Combretaceae-Melastomataceae & 4 & 1 & 1 & s & 4 & 4 & 0 & 3 & 0 & 0 & 1 & 2 & 4 & 4 & 5 \\
\hline Laguncularia & 0 & $i$ & 0 & 0 & 0 & 4 & 1 & 3 & 3 & 3 & 3 & $i$ & 1 & 4 & 10 \\
\hline Compositae high-spine & 1 & 5 & 4 & 2 & 3 & 2 & 2 & 2 & 1 & 5 & 3 & 5 & 0 & 0 & 1 \\
\hline Compositae low-spine & 0 & 0 & 0 & 0 & 0 & 0 & 1 & 0 & 0 & 0 & 0 & 0 & 0 & 0 & 0 \\
\hline Weinmannia & 0 & 0 & 1 & 0 & 0 & 0 & 0 & 0 & 0 & 0 & 0 & 0 & 0 & 1 & 0 \\
\hline Cyperaceae & 4 & 4 & 5 & 3 & 5 & 8 & 5 & 5 & 14 & 5 & 8 & 4 & 2 & 2 & 3 \\
\hline Ericaceae & 0 & 0 & 0 & 0 & 0 & 0 & 0 & 0 & 0 & 0 & 1 & 0 & 0 & 0 & 0 \\
\hline Acalypha & 1 & 2 & 0 & 1 & 1 & 1 & 1 & 0 & 0 & 2 & 0 & 0 & 0 & 0 & 0 \\
\hline Alchornea & 4 & 3 & 2 & 2 & 1 & 0 & 3 & 0 & 0 & 0 & 0 & 2 & 9 & 2 & 4 \\
\hline Crotonoideae & 0 & 0 & 0 & 0 & 0 & 0 & 0 & 0 & 0 & 0 & 0 & 0 & 0 & 0 & 0 \\
\hline Sapium-type & 0 & 0 & 0 & 0 & 0 & 0 & 0 & 0 & 0 & 0 & 1 & 0 & 0 & 0 & 0 \\
\hline ERA-type & 1 & 2 & 4 & 5 & 3 & 3 & 2 & 4 & 5 & 4 & 2 & 1 & 4 & 5 & 2 \\
\hline Quercus & 18 & 31 & 46 & 68 & 27 & 35 & 27 & 24 & 28 & 29 & 39 & 23 & 26 & 118 & 23 \\
\hline Gramineae & 4 & 15 & 8 & 24 & 9 & 8 & 10 & 20 & 15 & 6 & 8 & 17 & 12 & 13 & 5 \\
\hline Alfaroa-Oreomunnea & 1 & 4 & 4 & 3 & 1 & 1 & 1 & 0 & 2 & 0 & 1 & 7 & 0 & 12 & 10 \\
\hline Juglans & 0 & 0 & 0 & 0 & 0 & $\mathrm{i}$ & 0 & 1 & 0 & 0 & 0 & 0 & 0 & 0 & 0 \\
\hline Malpighiaceae & 1 & 0 & 0 & 0 & 0 & 0 & 0 & 0 & 0 & 0 & 0 & 0 & 0 & 2 & 1 \\
\hline Byrsonima & 0 & 0 & 0 & 0 & 0 & 0 & 0 & 0 & 0 & 0 & 0 & 0 & 0 & 0 & 0 \\
\hline Malvaceae & 0 & 0 & 0 & 0 & 0 & 0 & 0 & 1 & 0 & 2 & 1 & 0 & 1 & 0 & 0 \\
\hline Mimosaceae tetrad & 0 & 0 & 0 & 0 & 0 & 0 & 0 & 0 & 0 & 0 & 0 & 0 & 0 & 0 & 0 \\
\hline Mimosaceae polyad & 0 & 0 & 0 & 0 & 0 & $i$ & 0 & 0 & 0 & 0 & 0 & 0 & 0 & 0 & 0 \\
\hline Rapanea-type & 0 & 0 & 0 & 0 & 0 & 0 & 0 & 0 & 0 & 0 & 0 & 0 & 0 & 0 & 0 \\
\hline Eugenia & 0 & 0 & 0 & 4 & 0 & 0 & 0 & 0 & 0 & 0 & 1 & 1 & 1 & 0 & i \\
\hline Psidium & 0 & 0 & 0 & 1 & 0 & 0 & 0 & 4 & 0 & 0 & 0 & 0 & 0 & 0 & 1 \\
\hline Onagraceae & 0 & 0 & 0 & 0 & 0 & 0 & 0 & 0 & 0 & 0 & 0 & 0 & 1 & 0 & 0 \\
\hline Palmae & 0 & 0 & 0 & 1 & 0 & 1 & 0 & 2 & 3 & 1 & 1 & 3 & 0 & 0 & 0 \\
\hline Iriartea-type & 0 & 0 & 0 & 0 & 0 & 0 & 0 & 0 & 0 & 0 & 0 & 0 & 0 & 0 & 0 \\
\hline Piper & 9 & 7 & 6 & 2 & 11 & 3 & 3 & 4 & 0 & 0 & 1 & 0 & 9 & 1 & 0 \\
\hline Thalictrum-type & 0 & 0 & 0 & $i$ & 0 & 0 & $i$ & 0 & 0 & 0 & 0 & 1 & 0 & i & 0 \\
\hline Rhizophora & 10 & 23 & 16 & 15 & 12 & 21 & 27 & 26 & 26 & 27 & 25 & 44 & 20 & 18 & 9 \\
\hline Zanthoxylum & 1 & 0 & 0 & 0 & 0 & 0 & 0 & 0 & 1 & 1 & 2 & 1 & 0 & 0 & 0 \\
\hline Salix-type & 0 & 0 & 0 & 0 & 0 & 0 & 2 & 0 & 0 & 2 & 0 & 0 & 0 & 0 & 0 \\
\hline Sapotaceae-Meliaceae & 1 & 0 & 0 & 0 & 0 & 0 & 0 & 0 & 0 & 0 & 0 & 0 & 1 & 0 & 1 \\
\hline Guazuma-type & 0 & 0 & 0 & 0 & 0 & 0 & 0 & 0 & 1 & 1 & 1 & 0 & 0 & 0 & 0 \\
\hline Mortoniodendron & 0 & 0 & 0 & 0 & 0 & 0 & 0 & 0 & 0 & 0 & 0 & 0 & 0 & 0 & 0 \\
\hline Luehea-type & 0 & 0 & 0 & 1 & 0 & 0 & 0 & 0 & 0 & 1 & 0 & 0 & 1 & 0 & 0 \\
\hline Typha & 0 & 0 & 0 & 0 & 0 & 0 & 0 & 1 & 0 & 0 & 0 & 0 & 0 & 0 & \\
\hline Ulmus & 0 & 1 & 0 & 2 & 2 & 1 & 0 & 0 & 0 & 1 & 0 & 1 & 0 & 0 & 1 \\
\hline Urticales (undiff.) & 23 & 23 & 12 & 12 & 40 & 16 & 14 & 9 & 7 & 6 & 7 & 13 & 19 & 10 & 20 \\
\hline Ficus & 0 & 0 & 0 & 0 & 1 & 0 & 0 & 0 & 0 & 0 & 0 & 0 & 0 & 0 & 0 \\
\hline Cecropia & 3 & 2 & 1 & 1 & 7 & 1 & 1 & 0 & 0 & 0 & 0 & 0 & 0 & 0 & 0 \\
\hline Celtis & 0 & 0 & 1 & 0 & 0 & 5 & 0 & 3 & 3 & 4 & 0 & 1 & 0 & 0 & 0 \\
\hline Trema & 0 & 0 & 2 & 0 & 0 & 1 & 0 & 0 & 0 & 0 & 1 & 2 & 0 & 1 & 0 \\
\hline Drimys & 0 & 0 & 1 & 0 & 0 & i & 0 & 0 & 0 & 0 & 0 & 0 & 0 & 0 & 0 \\
\hline Avicennia & 0 & 0 & 0 & 0 & 0 & 1 & 0 & 0 & 1 & 0 & 0 & 0 & 0 & 1 & 0 \\
\hline Tricolpate-type 2 & 0 & 0 & 0 & 0 & 0 & 0 & 0 & 0 & 1 & 0 & 1 & 2 & 0 & 0 & 0 \\
\hline Cnemidaria & 0 & 0 & 0 & 0 & 0 & 0 & 0 & 0 & 0 & 0 & 0 & 0 & 0 & 0 & 1 \\
\hline Cyathea & 0 & 0 & 1 & 0 & 0 & 0 & 0 & 0 & 0 & 0 & 0 & 1 & 1 & 0 & 1 \\
\hline Pteris & 0 & 1 & 1 & 0 & 1 & 0 & 1 & 0 & 0 & i & 0 & 0 & $\mathrm{i}$ & 0 & 2 \\
\hline Hymenophyllaceac & 2 & 2 & 0 & 3 & 0 & 0 & 2 & 1 & 1 & 0 & 0 & 0 & 1 & 0 & 0 \\
\hline Ophioglossaceae & 0 & 0 & 0 & 0 & 0 & 0 & $i$ & 0 & 0 & 2 & 0 & 0 & i & 0 & 0 \\
\hline Polypodiaceae & 1 & 3 & 3 & 5 & 2 & 7 & $i$ & 2 & 0 & 3 & 5 & 3 & 2 & 3 & 6 \\
\hline Monolete Spores & 17 & 22 & 20 & 6 & 23 & 26 & 22 & 18 & 23 & 32 & 19 & 11 & 18 & 27 & 52 \\
\hline Trilete Spores & 20 & 18 & 17 & 14 & 28 & 24 & 22 & 26 & 26 & 30 & 27 & 15 & 22 & 16 & 29 \\
\hline Unknown pollen & 16 & 23 & 14 & 13 & 21 & 38 & 9 & 17 & 16 & 21 & 13 & 15 & 26 & 13 & 18 \\
\hline Indeterminate pollen & 70 & 36 & 62 & 48 & 42 & 40 & 33 & 36 & 31 & 45 & 41 & 56 & 45 & 59 & 49 \\
\hline Total pollen + spores & 259 & 272 & 263 & 255 & 298 & 355 & 255 & 264 & 270 & 317 & 259 & 277 & 265 & 378 & 295 \\
\hline Total pollen & 219 & 226 & 221 & 227 & 244 & 298 & 206 & 217 & 219 & 249 & 218 & 247 & 219 & 332 & 204 \\
\hline Total Urticales & 26 & 25 & 16 & 13 & 48 & 23 & 15 & 13 & 10 & 10 & 8 & 16 & 19 & 11 & 20 \\
\hline Controls & 125 & 156 & 75 & 103 & 140 & 187 & 203 & 239 & 190 & 219 & 113 & 238 & 100 & 208 & 200 \\
\hline $\begin{array}{l}\text { Pollen and Spores/g } \\
\text { (dry wt.) }\end{array}$ & 13586 & 17873 & 23241 & 23935 & 15341 & 17318 & 11769 & 12848 & 13735 & 12644 & 13086 & 10114 & 21883 & 14899 & 10056 \\
\hline
\end{tabular}

Note: Taxa are listed in alphabetical order by family, with gymnosperms first, followed by angiosperms and pteridophytes. Counts for genera in the Moraceae and Ulmaceae families are listed under the order Urticales. Unidentified spore types have been grouped together as Monolete and Trilete spores. See Horn (1983) for a more complete breakdown of the spore data.

a The TCT group includes pollen of the Taxodiaceae, Cupressaceae, and Taxaceae families. 
Appendix A. (Continued).

\begin{tabular}{|c|c|c|c|c|c|c|c|c|c|c|c|c|c|c|c|c|}
\hline \multicolumn{17}{|c|}{$\begin{array}{l}\text { Sample (interval in cm) } \\
\text { (sub-bottom depth in meters) }\end{array}$} \\
\hline $\begin{array}{c}1-5, \\
125-127\end{array}$ & $\begin{array}{l}1-6, \\
75-77\end{array}$ & $\begin{array}{c}1.7 \\
25-27\end{array}$ & $\begin{array}{l}2-1 \\
25-27\end{array}$ & $\begin{array}{l}2-1, \\
125-127\end{array}$ & $\begin{array}{l}2-2, \\
74-76\end{array}$ & $\begin{array}{l}2.3 \\
25-27\end{array}$ & $\begin{array}{l}2-3, \\
125-127\end{array}$ & $\begin{array}{l}2-4, \\
74-76\end{array}$ & $25-27$ & $\begin{array}{l}2-5 \\
125-127\end{array}$ & $\begin{array}{l}2-6,6 \\
75-77\end{array}$ & $\begin{array}{c}2-7 \\
25-27\end{array}$ & $\begin{array}{l}3-1, \\
70-72\end{array}$ & $\begin{array}{r}3-2, \\
27-29\end{array}$ & $\begin{array}{l}3-2, \\
125-127\end{array}$ & $\begin{array}{r}3-3, \\
74-76\end{array}$ \\
\hline & & & & & & & & & & & & & & & & \\
\hline 0 & 0 & 0 & 1 & 2 & 0 & 0 & 0 & 1 & 0 & 0 & 0 & 1 & 1 & 0 & 0 & 0 \\
\hline 22 & 30 & 38 & 12 & 30 & 18 & 20 & 51 & 33 & 15 & 7 & 15 & 8 & 6 & 8 & 8 & 12 \\
\hline 21 & 17 & 2 & 4 & 8 & 4 & 16 & 11 & 6 & 4 & 5 & 2 & 3 & 8 & 2 & 4 & 6 \\
\hline 3 & 3 & 0 & 1 & 3 & 1 & 1 & 2 & 1 & 2 & 0 & 1 & 3 & 1 & 1 & 0 & 3 \\
\hline 1 & 2 & 0 & 0 & 2 & 3 & 0 & 3 & 0 & $i$ & 3 & 0 & 0 & 1 & 3 & 0 & 1 \\
\hline 0 & 2 & 0 & 0 & 0 & 0 & 0 & $i$ & 0 & 0 & 0 & 1 & 0 & 0 & 1 & 0 & 0 \\
\hline 0 & 2 & 0 & 4 & 0 & 0 & 2 & 3 & 3 & 0 & $i$ & 1 & 2 & 1 & 0 & 0 & 2 \\
\hline 0 & 1 & 0 & 0 & 0 & 2 & 0 & 1 & 0 & 0 & 3 & 0 & 0 & 0 & 0 & 2 & 1 \\
\hline 0 & 0 & 0 & 0 & 0 & 0 & 0 & 0 & 0 & 0 & 0 & 0 & 0 & 0 & 3 & 0 & $i$ \\
\hline 6 & 6 & 4 & 4 & 6 & 5 & 1 & 0 & 3 & 5 & 9 & 6 & 6 & 2 & 5 & 10 & 7 \\
\hline 0 & 0 & 0 & 0 & 0 & 0 & 1 & 0 & 0 & 0 & I & 1 & 0 & 1 & 0 & 0 & 0 \\
\hline 0 & 0 & 0 & 0 & 0 & 0 & $i$ & 1 & 0 & 0 & 0 & 0 & 0 & i & 1 & 2 & 0 \\
\hline 1 & 1 & 0 & 1 & 0 & 1 & 3 & i & 0 & 0 & 0 & 2 & 1 & 1 & 0 & 0 & 0 \\
\hline 0 & 0 & 0 & 0 & 0 & $i$ & 0 & 0 & 0 & 1 & 1 & 0 & 0 & 0 & 0 & 0 & 1 \\
\hline 2 & 1 & 4 & 1 & 3 & $i$ & 3 & 4 & 0 & 4 & 2 & 2 & 4 & 2 & 0 & 2 & 2 \\
\hline 4 & 8 & 11 & 3 & 5 & 7 & 4 & 0 & 3 & 7 & 7 & 4 & 6 & $i$ & 4 & 6 & 2 \\
\hline 4 & 0 & 0 & 0 & 0 & 3 & 3 & 5 & 1 & 8 & 9 & 10 & 5 & 8 & 3 & 6 & i \\
\hline 1 & 5 & 3 & 3 & 2 & 1 & 5 & 1 & 6 & 1 & 4 & 4 & 2 & 1 & 4 & 2 & 5 \\
\hline 0 & 0 & 0 & 1 & 1 & 0 & 0 & 0 & 1 & 0 & 1 & 0 & 1 & 0 & 1 & 0 & 0 \\
\hline 0 & 0 & 0 & 0 & 0 & 0 & 0 & 0 & 0 & 0 & 0 & 1 & 0 & 0 & 0 & 2 & 0 \\
\hline 2 & 1 & 12 & 8 & 7 & 4 & 8 & 12 & 14 & 11 & 3 & 4 & 5 & 7 & 3 & 4 & 4 \\
\hline 0 & 0 & 0 & 0 & 0 & 0 & 0 & 0 & 0 & i & 0 & 0 & I & 0 & 0 & 0 & 0 \\
\hline 0 & 0 & 1 & 0 & 0 & 0 & 0 & 0 & 0 & $i$ & 0 & 1 & 0 & 0 & 0 & 0 & 0 \\
\hline 1 & 0 & 0 & 0 & 0 & 0 & 0 & 0 & 0 & 2 & 3 & $i$ & 0 & 6 & 3 & 2 & 2 \\
\hline$i$ & 0 & 2 & 1 & 0 & 0 & 0 & 0 & 0 & 0 & 0 & 0 & 0 & 0 & 0 & 0 & 0 \\
\hline 0 & 0 & 0 & 0 & 0 & 1 & 0 & 2 & 1 & 1 & 3 & 4 & 0 & 0 & 0 & 0 & 0 \\
\hline 2 & 4 & 11 & 0 & 6 & 8 & 9 & 5 & 3 & 7 & 12 & 3 & 2 & 5 & 4 & 6 & 6 \\
\hline 33 & 37 & 50 & 34 & 45 & 52 & 30 & 84 & 57 & 30 & 25 & 18 & 27 & 18 & 23 & 24 & 17 \\
\hline 5 & 11 & 12 & 9 & 5 & 10 & 12 & 12 & 15 & 11 & 22 & 22 & 20 & 7 & 7 & i1 & 13 \\
\hline 3 & 1 & 7 & 3 & 1 & 3 & 4 & 5 & 13 & 9 & 9 & 5 & 4 & 5 & 0 & 4 & 0 \\
\hline 0 & 0 & 0 & 0 & 0 & 0 & 0 & $i$ & 1 & 1 & 0 & 0 & 1 & 0 & 0 & 1 & 0 \\
\hline 1 & 0 & 0 & 0 & 1 & 0 & 1 & 2 & i & 1 & 5 & 4 & 1 & 0 & 0 & 2 & 1 \\
\hline 0 & 0 & 0 & 0 & 0 & 0 & 0 & 0 & 0 & 0 & 0 & 0 & 0 & 0 & 2 & $i$ & $\mathrm{i}$ \\
\hline 0 & 0 & 0 & 0 & 0 & 0 & 0 & 0 & 0 & 0 & 0 & 0 & 0 & 0 & 0 & 0 & 0 \\
\hline 0 & 0 & 0 & 0 & 0 & 0 & 0 & 0 & i & 0 & 0 & 1 & 0 & 0 & 0 & 0 & 1 \\
\hline 0 & 1 & 0 & 0 & 0 & 0 & 0 & 0 & 0 & 0 & 0 & i & 0 & 0 & 0 & 0 & 0 \\
\hline 0 & 0 & 0 & 0 & 0 & 1 & 0 & 0 & 0 & 0 & 0 & 0 & 0 & 0 & 0 & 1 & 1 \\
\hline 2 & 0 & 0 & 0 & 1 & 0 & 0 & 0 & 1 & 3 & 2 & 2 & 3 & 0 & 0 & 1 & 1 \\
\hline 0 & 2 & 1 & 2 & $i$ & 1 & 0 & 1 & $i$ & 4 & $i$ & 5 & 0 & 0 & 1 & 5 & 0 \\
\hline 0 & 1 & 0 & 0 & 0 & 0 & 0 & 0 & $i$ & 0 & 0 & 0 & 0 & 0 & 0 & 0 & 0 \\
\hline 0 & 0 & 0 & 0 & 0 & 0 & 0 & 1 & 1 & 2 & 2 & 0 & i & 0 & 1 & 0 & 0 \\
\hline 0 & 0 & 1 & 0 & 0 & 1 & 1 & 1 & 0 & 0 & 0 & 0 & 0 & 0 & 0 & 1 & 0 \\
\hline 1 & 2 & 0 & 1 & 1 & 1 & 5 & 5 & 1 & 12 & 34 & 20 & 7 & 9 & 16 & 3 & 9 \\
\hline 0 & 1 & 2 & 1 & 0 & 1 & 0 & 3 & 0 & 0 & 0 & 0 & 1 & 0 & 0 & 0 & 0 \\
\hline 18 & 43 & 24 & 28 & 28 & 16 & 14 & 20 & 15 & 69 & 26 & 91 & 16 & 39 & 47 & 33 & 35 \\
\hline 3 & 0 & 0 & 0 & 0 & 1 & 0 & 2 & 1 & 2 & 0 & 3 & 0 & 1 & 0 & 0 & 0 \\
\hline 0 & 0 & 0 & 0 & 0 & 0 & 0 & 0 & $i$ & 0 & 0 & 1 & 0 & 0 & 0 & 0 & 0 \\
\hline 0 & 1 & 0 & 0 & 0 & 0 & 0 & 0 & 0 & 0 & 0 & 0 & i & 0 & 1 & 0 & 0 \\
\hline 0 & 0 & 0 & 1 & 1 & 0 & 0 & 0 & 0 & 0 & 0 & 0 & 0 & 0 & 0 & 0 & 0 \\
\hline 0 & 0 & 1 & 0 & 0 & 0 & 0 & 0 & 0 & 0 & 0 & 2 & 0 & 0 & 1 & 0 & 0 \\
\hline 0 & 0 & 0 & 0 & 0 & 0 & 0 & 0 & 0 & 0 & 0 & 0 & 0 & 0 & 0 & 0 & 0 \\
\hline 0 & 0 & 0 & 0 & 0 & 1 & 0 & 0 & 0 & 0 & 1 & 0 & 0 & 0 & 0 & 0 & 0 \\
\hline 2 & 0 & 1 & 0 & 0 & 1 & 0 & 0 & 1 & 0 & 2 & 0 & 0 & 2 & 0 & 3 & 1 \\
\hline 18 & 10 & 3 & 8 & 18 & 7 & 10 & 11 & 6 & 13 & 23 & 13 & 12 & 24 & 27 & 19 & 16 \\
\hline 0 & 0 & 0 & 0 & 0 & 0 & 0 & 0 & 0 & 0 & 2 & 0 & 0 & 2 & 1 & 1 & 0 \\
\hline 0 & 0 & 0 & 0 & 0 & 0 & 0 & 0 & 0 & 0 & 0 & 0 & 0 & 0 & 0 & 0 & 0 \\
\hline 3 & 1 & 4 & 6 & i & 1 & 3 & 3 & 3 & 3 & 6 & 3 & 2 & 6 & 7 & 4 & 9 \\
\hline 0 & 0 & 0 & 0 & 0 & 1 & 0 & 0 & 0 & 0 & 3 & 0 & 0 & 2 & 0 & 0 & 1 \\
\hline 0 & 0 & 0 & 0 & 0 & 0 & 0 & 0 & 0 & 0 & 0 & 0 & 0 & 0 & 0 & 0 & 1 \\
\hline 0 & 0 & 0 & 0 & 0 & 0 & 0 & 0 & 0 & 0 & 0 & 0 & 0 & 0 & 0 & 0 & 0 \\
\hline 0 & 0 & 0 & 0 & 0 & 0 & 0 & 0 & 0 & 0 & 0 & 0 & i & 2 & 1 & 0 & 0 \\
\hline 0 & 0 & 2 & 0 & 0 & 0 & 1 & 0 & 0 & 3 & 1 & 0 & 1 & 0 & 0 & 0 & 0 \\
\hline 0 & 0 & 0 & 0 & 0 & 0 & 0 & 0 & 0 & 0 & 0 & 0 & 0 & 0 & 0 & 0 & 0 \\
\hline 0 & 2 & 1 & 0 & 2 & 1 & 0 & 1 & 0 & 0 & 4 & 1 & 0 & 0 & 2 & 4 & 0 \\
\hline 2 & 0 & 0 & 0 & 0 & 0 & 0 & 0 & 3 & 0 & 0 & 0 & 0 & 0 & 0 & 0 & 0 \\
\hline 0 & 0 & 1 & 0 & 1 & 0 & 2 & 1 & 2 & 0 & 2 & 0 & 0 & 0 & 0 & 0 & 0 \\
\hline 8 & 8 & 5 & 1 & 4 & 4 & 6 & 3 & 9 & 4 & 3 & 4 & 12 & 1 & 3 & 11 & 8 \\
\hline 21 & 20 & 21 & 31 & 24 & 19 & 34 & 23 & 15 & 50 & 37 & 13 & 36 & 29 & 34 & 26 & 24 \\
\hline 13 & 18 & 20 & 18 & 28 & 10 & 20 & 13 & 16 & 36 & 50 & 23 & 20 & 14 & 15 & 21 & 14 \\
\hline 20 & 44 & 57 & 50 & 39 & 25 & 18 & 26 & 21 & 34 & 56 & 52 & 32 & 24 & 27 & 32 & 13 \\
\hline 38 & 62 & 33 & 38 & 59 & 36 & 50 & 46 & 31 & 65 & 107 & 63 & 51 & 40 & 43 & 41 & 57 \\
\hline 263 & 350 & 335 & 276 & 336 & 253 & 290 & $\begin{array}{l}40 \\
368\end{array}$ & $\begin{array}{r}31 \\
293\end{array}$ & 423 & 503 & 412 & 300 & 278 & 305 & 306 & 280 \\
\hline 219 & 302 & 285 & 226 & 277 & 219 & 226 & 330 & 247 & 331 & 406 & 372 & 231 & 234 & 251 & 242 & 235 \\
\hline 21 & 11 & 7 & 14 & 19 & 9 & 13 & 14 & 9 & 17 & 34 & 16 & 14 & 34 & 35 & 24 & 26 \\
\hline 169 & 252 & 169 & 255 & 289 & 165 & 209 & 157 & 112 & 354 & 310 & 189 & 172 & 168 & 157 & 182 & 252 \\
\hline 11764 & 9536 & 11660 & 7449 & 7696 & 8935 & 8452 & 15014 & 13306 & 6295 & 7910 & 11453 & 9326 & 9241 & 9442 & 10825 & 6349 \\
\hline
\end{tabular}


APPENDIX B

Infrequently Appearing Pollen and Spores, Site 565

\begin{tabular}{|c|c|c|c|}
\hline Taxon & No. & $\begin{array}{c}\text { Sample } \\
\text { (interval in } \mathrm{cm} \text { ) }\end{array}$ & $\begin{array}{c}\text { Depth } \\
\text { sub-bottom } \\
\text { (m) }\end{array}$ \\
\hline Aphelandra & 1 & $1-1,26-28$ & .26 \\
\hline Bravaisia & 1 & $2-5,125-127$ & 17.75 \\
\hline Hygrophila-type & 1 & $1-5,25-27$ & 6.25 \\
\hline \multirow[t]{2}{*}{ Gomphrena-type } & 1 & $2-5,125-127$ & 17.75 \\
\hline & 1 & $2-6,75-77$ & 18.75 \\
\hline Tournefortia & 1 & $1-5,125-127$ & 7.25 \\
\hline \multirow[t]{2}{*}{ Liguliflorae } & 1 & $1-4,75-77$ & 5.25 \\
\hline & 1 & $2-3,25-27$ & 13.75 \\
\hline Symphonia & 1 & $1-6,75-77$ & 8.25 \\
\hline Liquidambar & 1 & $1-1,125-127$ & 1.25 \\
\hline \multirow[t]{2}{*}{ Liliaceae } & 1 & $1-1,26-28$ & .26 \\
\hline & 1 & $1-1,76-78$ & .76 \\
\hline Abutilon-type & 1 & $2-3,25-27$ & 13.75 \\
\hline Hibiscus & 1 & $2-5,125-127$ & 17.75 \\
\hline Dorstenia & 1 & $2-5,25-27$ & 16.75 \\
\hline Virola & 1 & $3-2,125-127$ & 22.75 \\
\hline Plantago & 1 & $1-6,75-77$ & 8.25 \\
\hline Polygonum & 1 & $1-7,25-27$ & 9.25 \\
\hline Rosaceae & 1 & $2-5,125-127$ & 17.75 \\
\hline \multirow[t]{2}{*}{ Cardiospermum } & 1 & $2-3,125-127$ & 14.75 \\
\hline & 1 & $2-7,25-27$ & 19.75 \\
\hline Pelliciera & 1 & $1-3,75-77$ & 3.75 \\
\hline Apeiba & 1 & $1-4,125-127$ & 5.75 \\
\hline \multirow[t]{2}{*}{ Umbelliferae } & 1 & $1-1,125-127$ & 1.25 \\
\hline & 1 & $2-6,75-77$ & 18.75 \\
\hline Tricolporate Type 35 & 1 & $2-1,125-127$ & 11.75 \\
\hline Tricolporate Type 40 & 1 & $2-1,25-27$ & 10.75 \\
\hline \multirow{2}{*}{ 6-porate Type 58} & 1 & $1-2,25-27$ & 1.75 \\
\hline & 2 & $2-5,125-127$ & 17.75 \\
\hline \multirow{2}{*}{ 6-colporate Type 59} & 1 & $1-2,25-27$ & 1.75 \\
\hline & 1 & $3-3,74-76$ & 23.74 \\
\hline
\end{tabular}



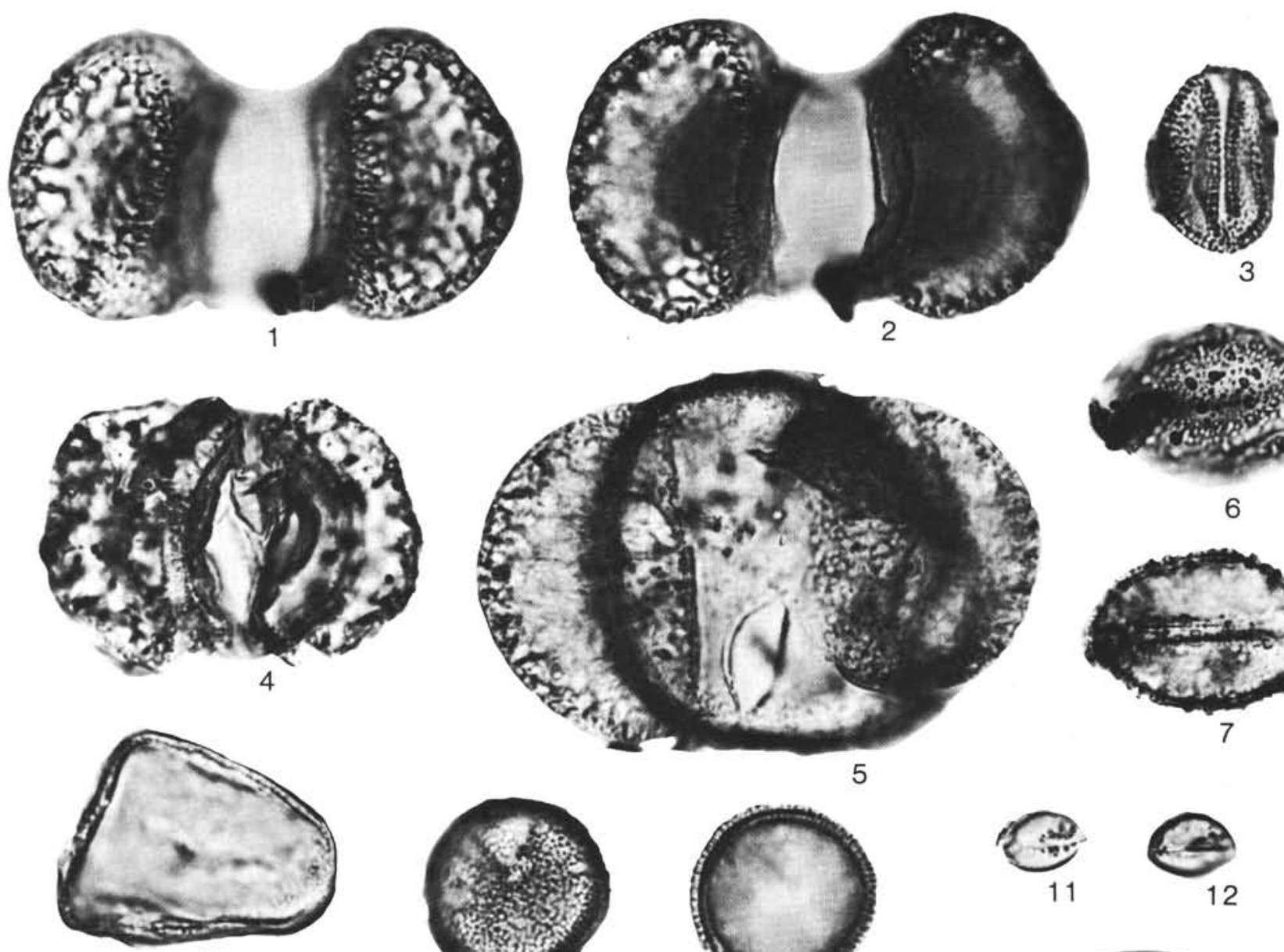

5

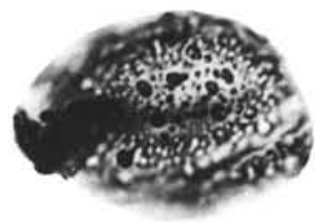

6

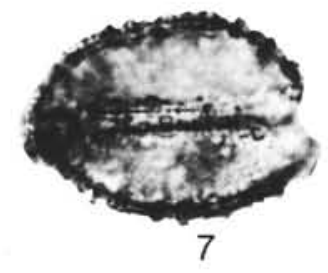

8

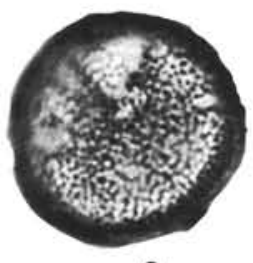

9

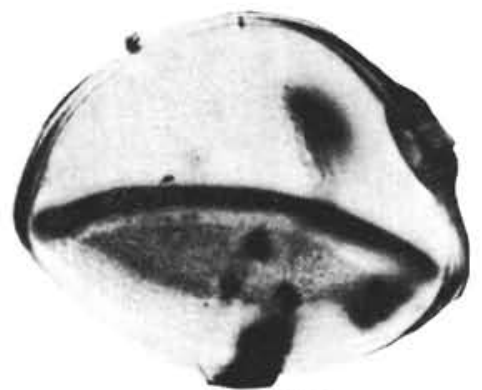

13

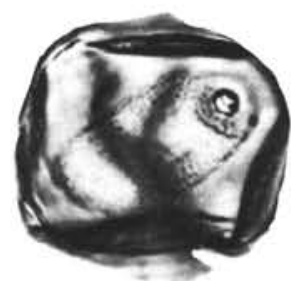

14

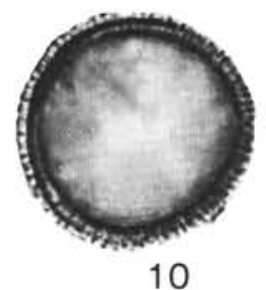

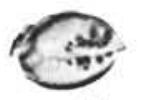

11

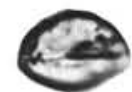

12

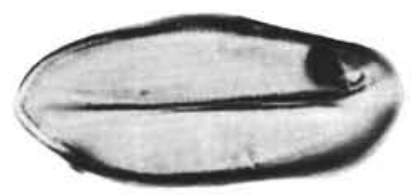

16

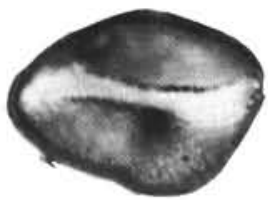

15

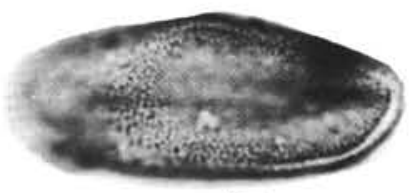

17

Plate 1. Pollen from Sections 565-1-1 through 565-3-3. (All magnifications $\times 1000$.) 1-2. Podocarpus, Sample 565-2-3, 25-27 cm, (1) high focus, (2) low focus. 3. Virola, Sample 565-3-2, 125-127 cm. 4. Podocarpus, Sample 565-1-6, 75-77 cm. 5. Pinus, Sample 565-1-4, 25-27 $\mathrm{cm}$. 6-7. Iriartea-type, Sample 565-2-3, 25-27 cm, (6) high focus, (7) low focus. 8. Cyperaceae, Sample 565-1-1, 76-78 cm. 9-10. Hedyosmum, Sample 565-1-1, 76-78 cm, (9) high focus, (10) low focus. 11-12. Piper, Sample 565-2-3, 25-27 cm, (11) high focus, (12) low focus. 13. Gramineae, Sample 565-1-1, 1-3 cm. 14. Gramineae, Sample 565-1-6, 75-77 cm. 15. Palmae, Sample 565-1-1, 36-38 cm. 16-17. Palmae, Sample 565-1-4, 75-77 cm, (16) high focus, (17) low focus. 


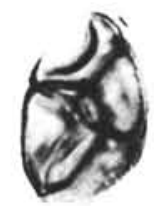

1

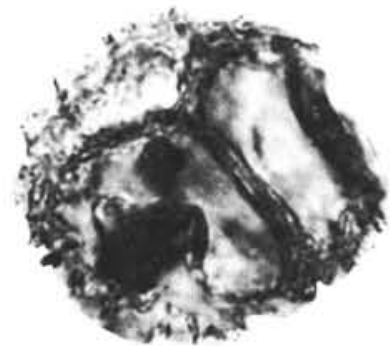

8

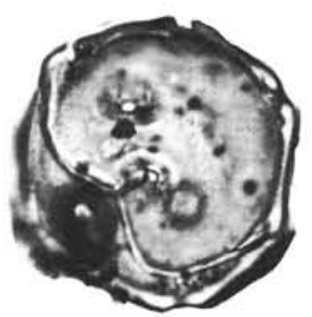

13

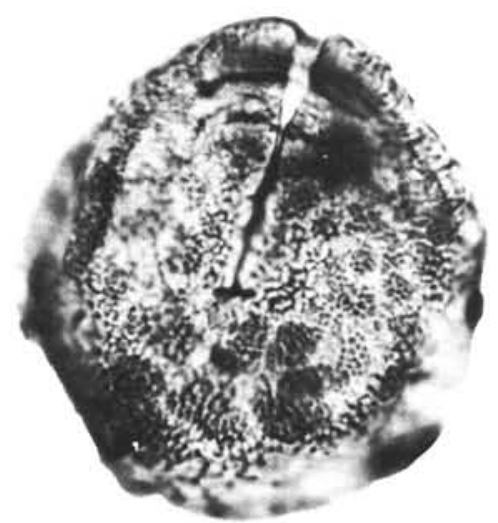

18

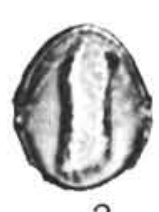

3

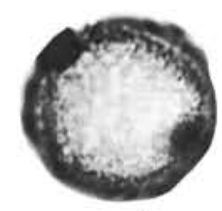

4

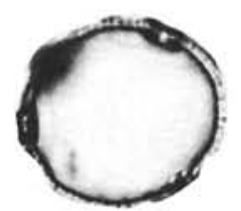

5

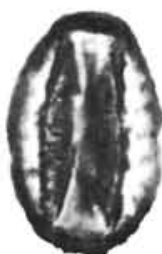

6

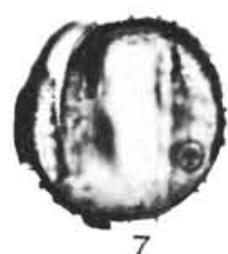

7
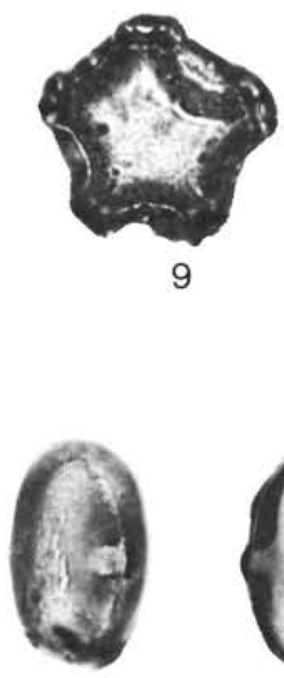

14

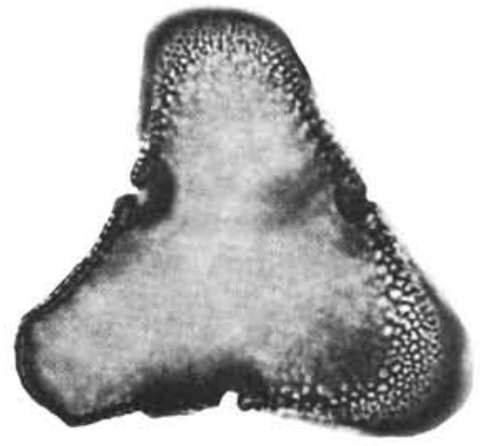

19

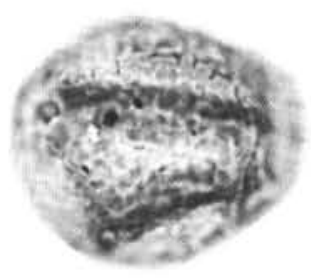

16

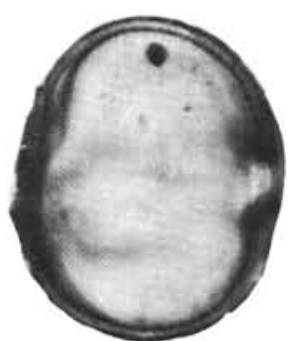

12

Plate 2. Pollen from Sections 565-1-1 through 565-3-3. (All magnifications $\times$ 1000.) 1. Mimosaceae tetrad, Sample 565-2-4, 75-77 cm. 2. Ficus, Sample 565-3-1, 70-72 cm. 3. Urticales, Sample 565-1-1, 76-78 cm. 4-5. Celtis, Sample 565-1-1, 76-78 cm, (4) high focus, (5) low focus. 6. Quercus, Sample 565-1-6, 75-77 cm. 7. Cordia, Sample 565-1-2, 25-27 cm. 8. Drimys, Sample 565-1-1, 76-78 cm. 9-10. Alnus, Sample 565-1-5, 125-127 cm, (9) high focus, (10) low focus. 11-12. Sapotaceae-Meliaceae, Sample 565-2-5, 125-127 cm, (11) high focus, (12) low focus. 13. Juglans, Sample 565-1-1, 1-3 cm. 14-15. Rapanea-type, Sample 565-2-2, 74-76 cm, (14) high focus, (15) low focus. 16-17. Ulmus, Sample 565-1-5, 125-127 cm, (16) high focus, (17) low focus. 18. Pelliciera rhizophorae, Sample 565-1-3, 75-77 cm. 19. Bombacaceae, Sample 565-1-4, 25-27 cm. 20-21. Spondias-type, Sample 565-1-2, 125-127 cm, (20) high focus, (21) low focus. 


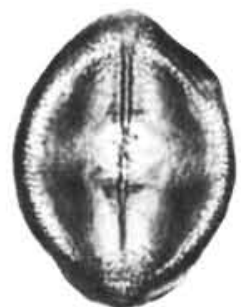

1

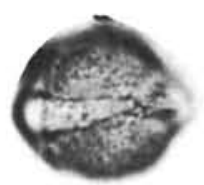

6

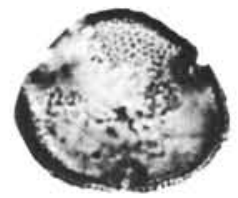

11

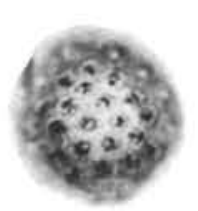

16

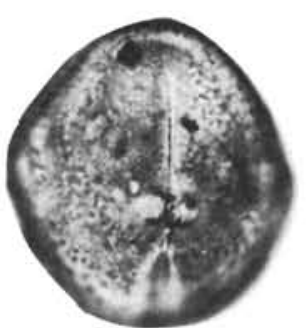

22
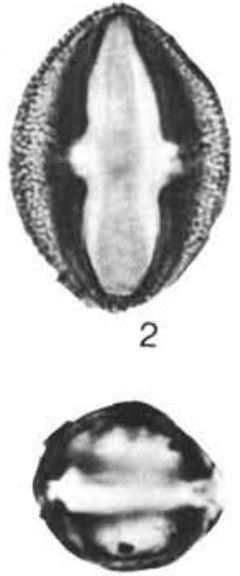

7

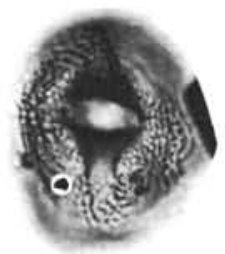

12

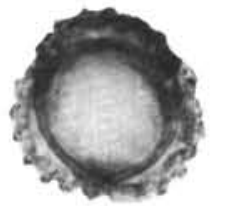

17

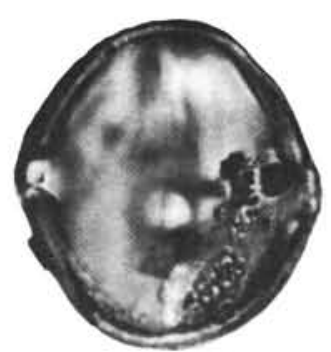

23

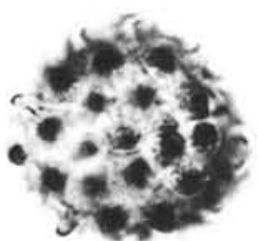

3

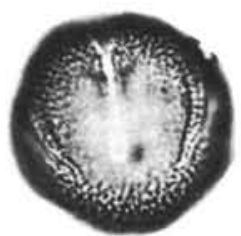

8

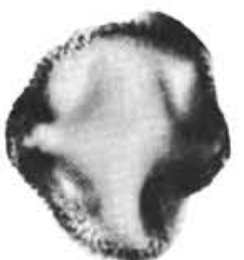

13

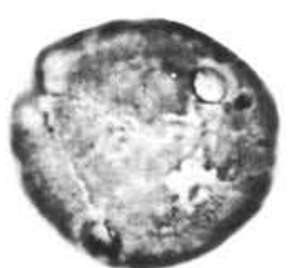

4

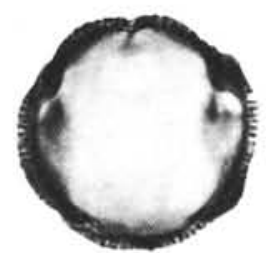

9

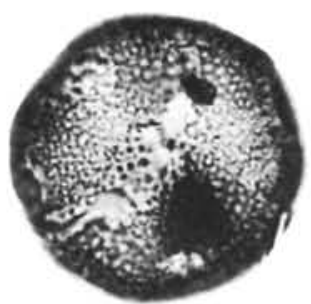

14
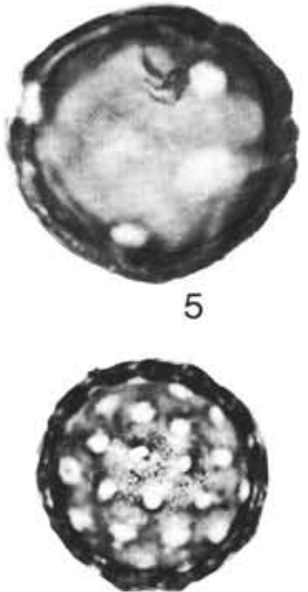

10

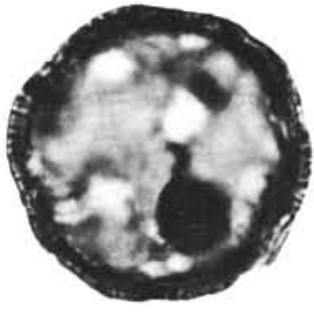

15

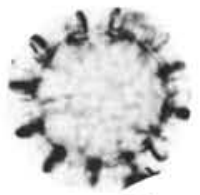

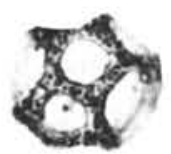

18

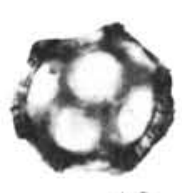

19

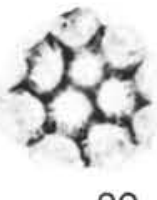

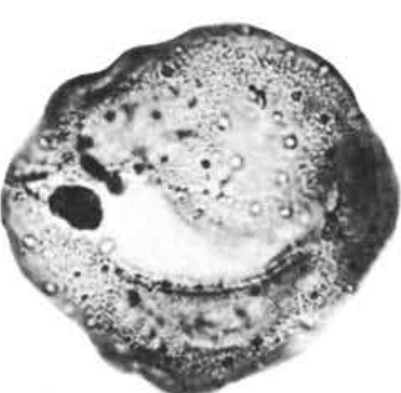

24
21

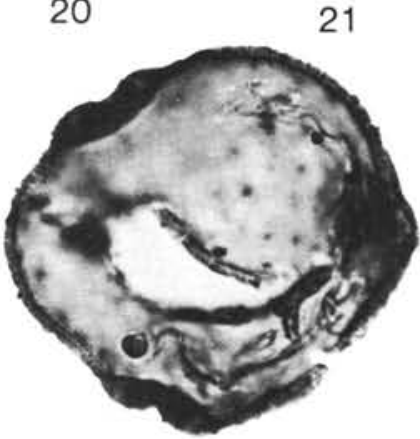

25

Plate 3. Pollen from Sections 565-1-1 through 565-3-3. (All magnifications $\times 1000$.) 1-2. Anacardium-type, Sample 565-1-6, 75-77 cm. 3. Malvaceae, Sample 565-1-4, 25-27 cm. 4-5. Malpighiaceae, Sample 565-1-1, 76-78 cm, (4) high focus, (5) low focus. 6-7. Rhizophora, Sample 565-1-2, 125-127 cm, (6) high focus, (7) low focus. 8-9. Unknown 6-colporate, Sample 565-1-2, 25-27 cm, (8) high focus, (9) low focus. 10. Amaranthaceae, Sample $565-2-3,25-27 \mathrm{~cm}$. 11. Mortoniodendron, Sample 565-2-6, 75-77 cm. 12-13. Bursera, Sample 565-1-1, 76-78 $\mathrm{cm}$, (12) high focus, (13) low focus. 14-15. Caryophyllaceae, Sample 565-1-3, 75-77 cm, (14) high focus, (15) low focus. 16-17. Compositae (low-spine type), Sample $565-2-5,125-127 \mathrm{~cm}$, (16) high focus, (17) low focus. 18-19. Alternanthera-type, Sample 565-1-5, 125-127 cm, (18) high focus, (19) low focus. 20-21. Gomphrena-type, Sample 565-2-5, 125-127 cm, (20) high focus, (21) low focus. 22-23. Unknown tricolporate, Sample 565-1-3, 75-77 cm, (22) high focus, (23) low focus. 24-25. Unknown tricolporate, Sample 565-2-3, 25-27 cm, (24) high focus, (25) low focus. 


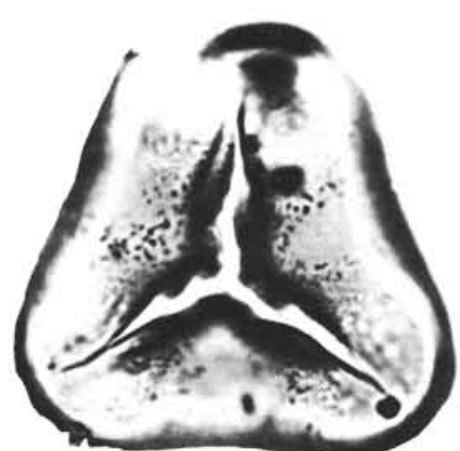

1

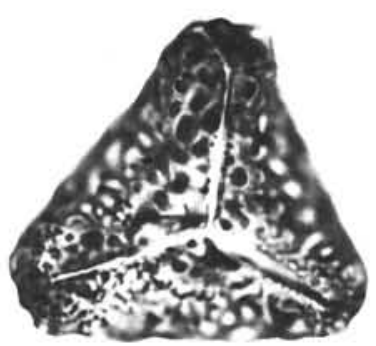

4
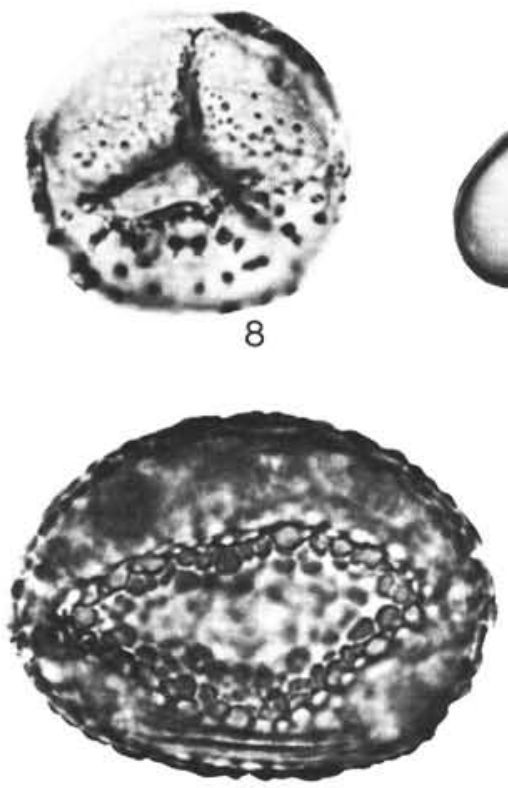

12
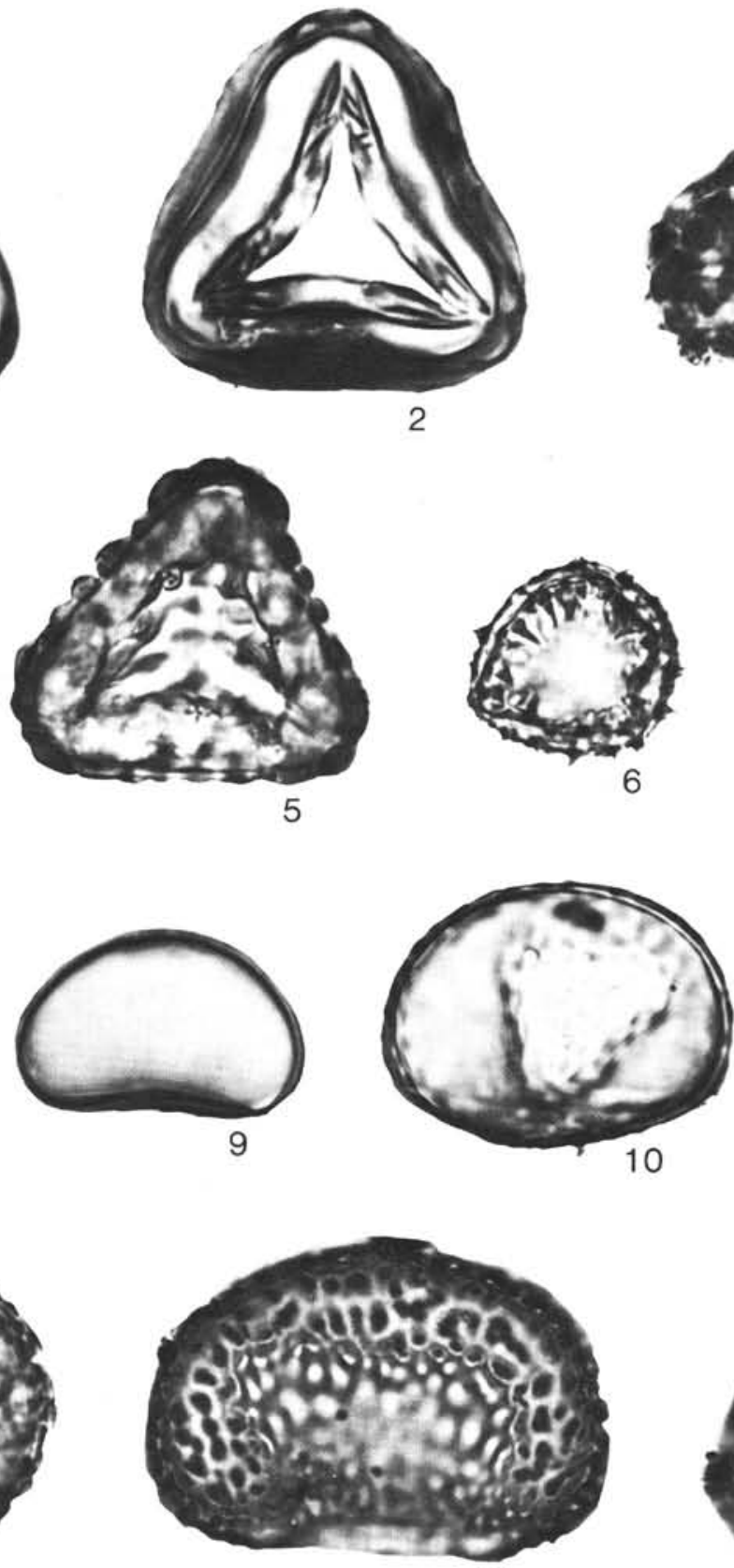

13
6
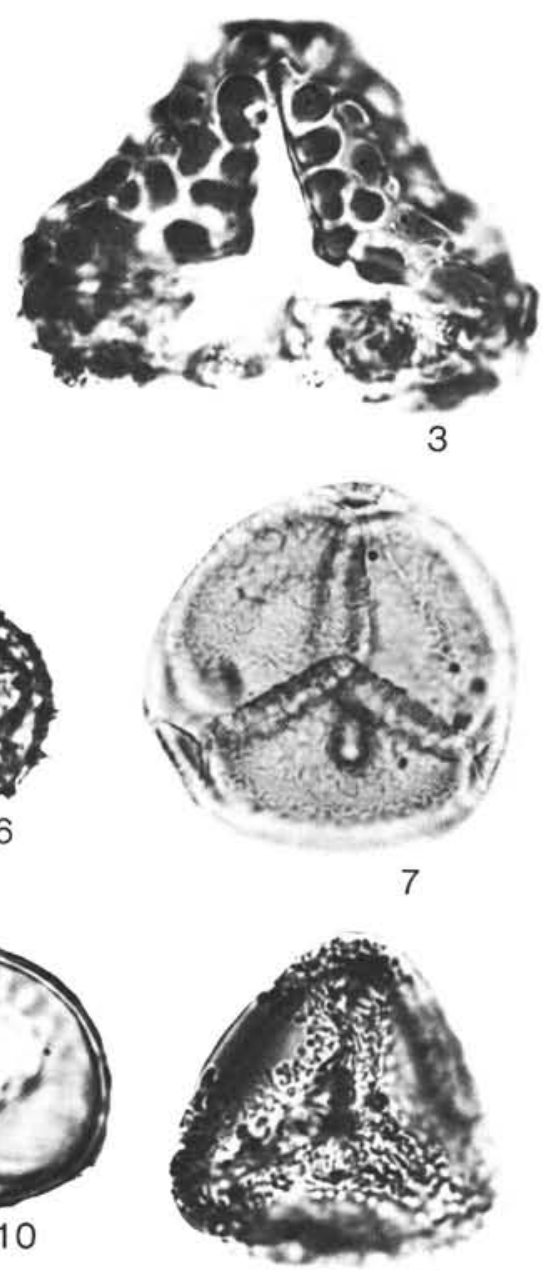

11

Plate 4. Spores from Site 565, Sections 565-1-1 through 565-3-3. (All magnifications $\times 1000$.) 1. Psilate trilete, Sample 565-1-6, 75-77 cm. 2. Psilate trilete, Sample 565-1-5, 125-127 cm. 3. Verrucate trilete, Sample 565-1-5, 125-127 cm. 4-5. Ophioglossaceae, Sample 565-1-6, 75-77 $\mathrm{cm}$, (4) high focus, (5) low focus. 6. Echinate trilete, Sample 565-1-6, 75-77 cm. 7. Hymenophyllaceae, Sample 565-1-5, 125-127 cm. 8. Hymenophyllaceae, Sample 565-1-5, 125-127 cm. 9. Psilate monolete, Sample 565-1-6, 75-77 cm. 10. Psilate monolete, Sample 565-1-6, 75$77 \mathrm{~cm}$. 11. Psilate trilete, showing effect of bacterial-fungal activity on spore wall, Sample $565-1-6,75-77 \mathrm{~cm}$. 12. Polypodiaceae, Sample $565-1-5,25-27 \mathrm{~cm}$. 13. Polypodiaceae, Sample 565-1-6, 75-77 cm. 14. Polypodiaceae, Sample 565-1-5, $25-27 \mathrm{~cm}$. 


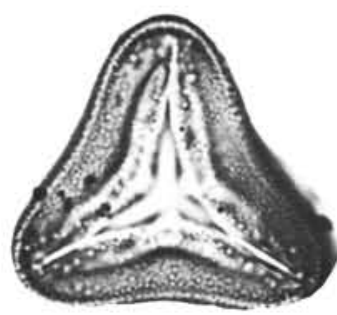

1

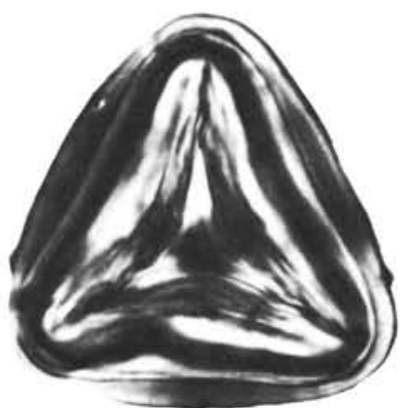

5

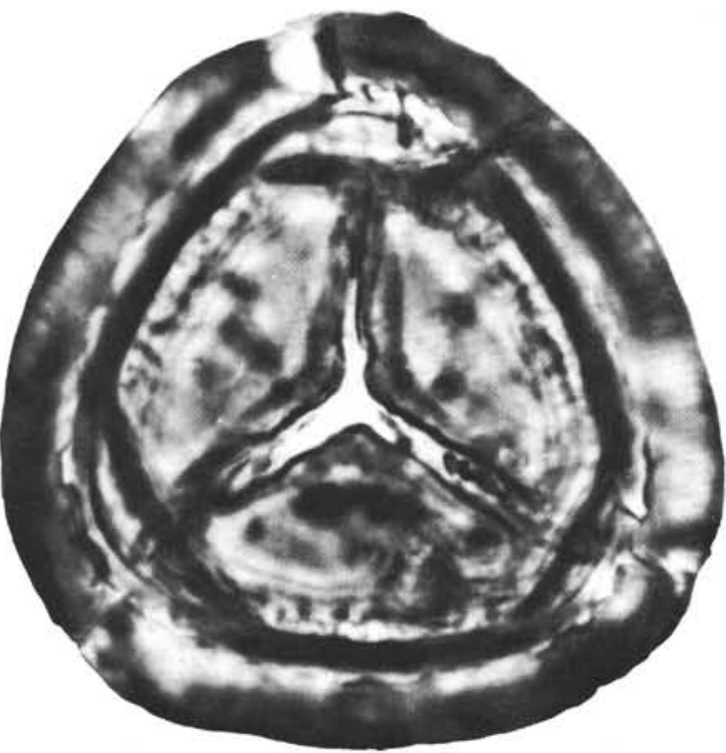

9
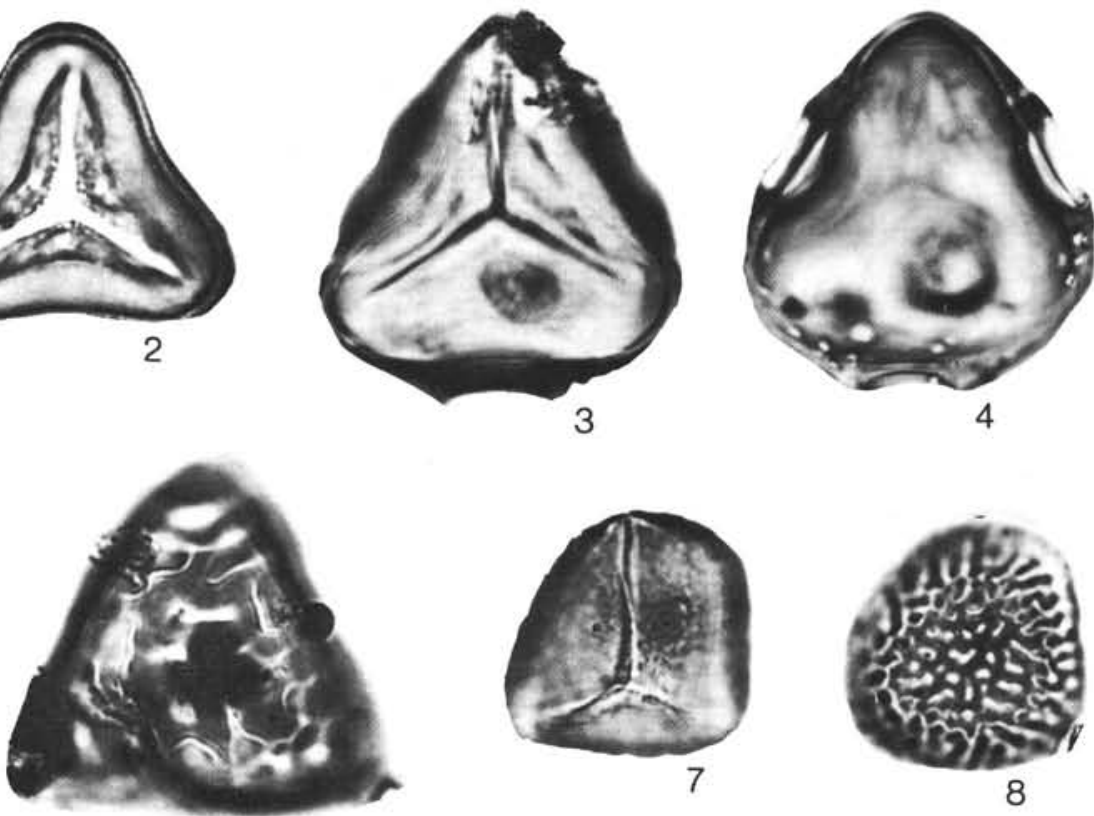

6
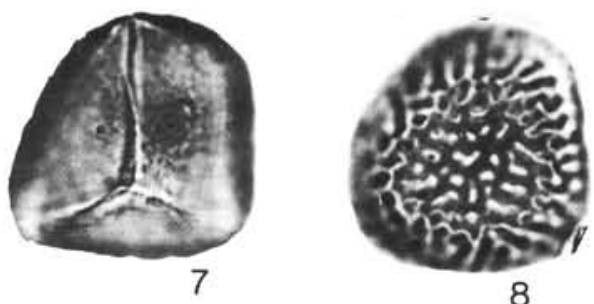

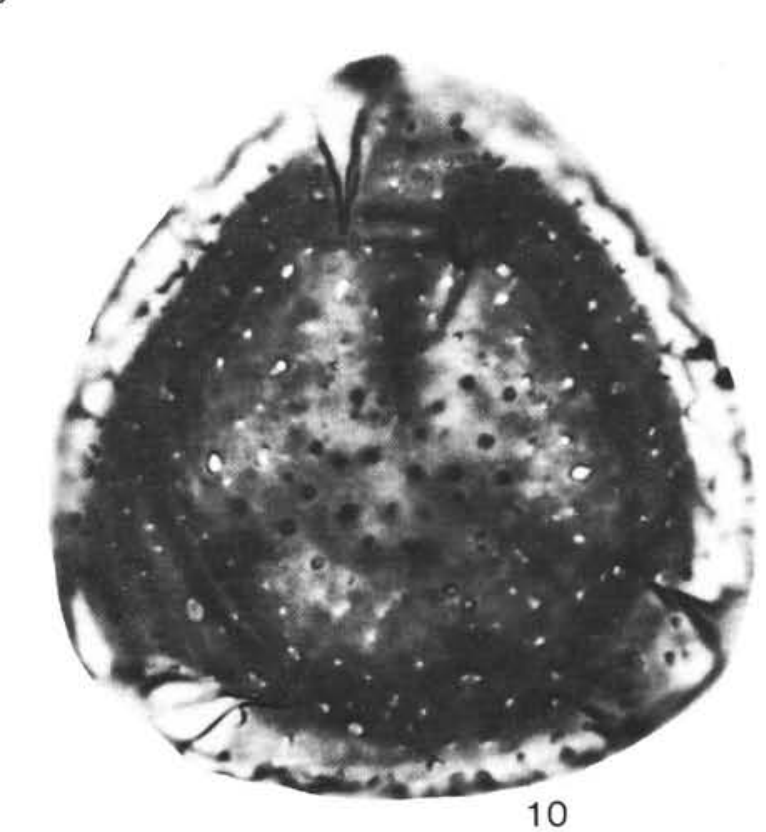

Plate 5. Spores from Sections 565-1-1 through 565-3-3. (All magnifications $\times 1000$.) 1-2. Cyathea, Sample 565-1-6, 75-77 cm, (1) high focus, (2) low focus. 3-4. Cnemidaria (= Hemitelia), Sample 565-2-3, 25-27 cm, (3) high focus, (4) low focus. 5-6. Pteris, Sample 565-1-5, 125-127 $\mathrm{cm}$, (5) proximal face, (6) distal face. 7-8. Reticulate trilete, Sample 565-1-6, 75-77 cm, (7) proximal face, (8) distal face. 9-10. Echinate trilete, Sample 565-1-3, 75-77 cm, (9) proximal face, (10) distal face. 